\title{
Degradation Mode Survey \\ Galvanic Corrosion of Candidate Metallic Materials for High-Level Radioactive Waste Disposal Containers
}

\author{
A.K. Roy \\ D.A. Jones \\ R.D. McCright
}

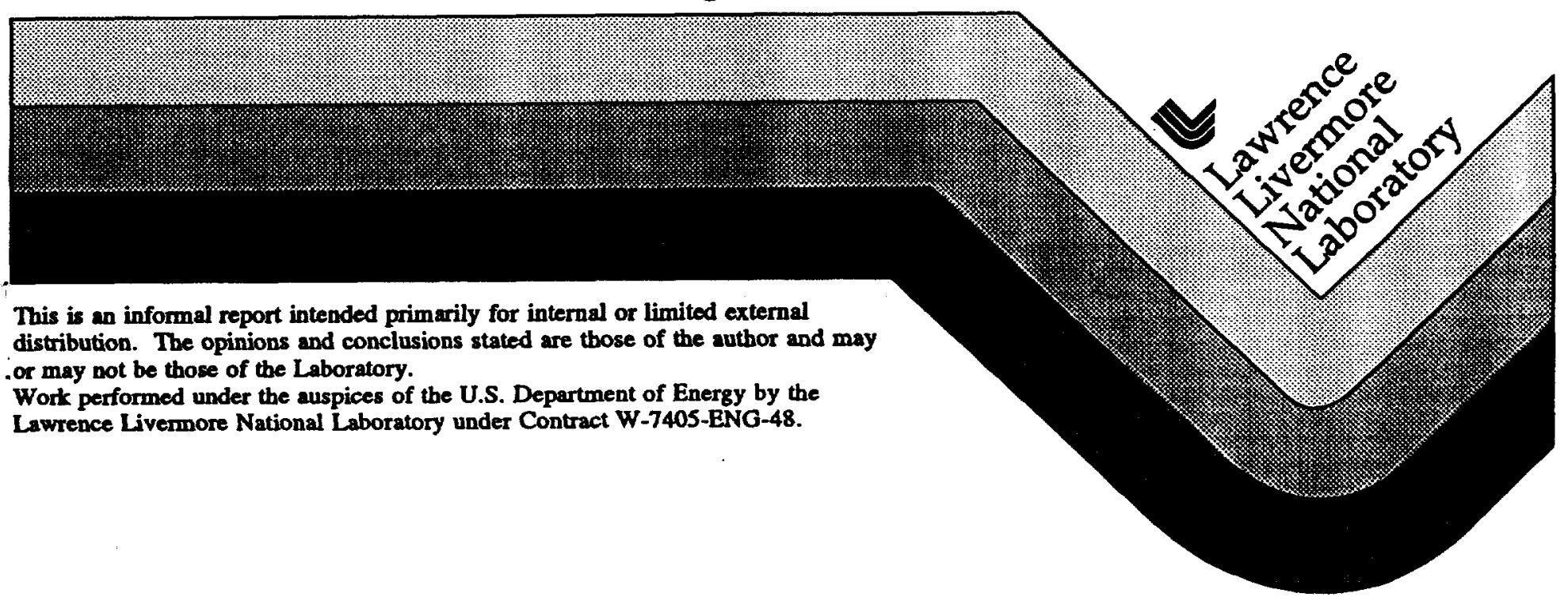




\section{DISCLAIMER}

This document was prepared as an account of work sponsored by an agency of the United States Government. Neither the United States Government nor the University of California nor any of their employees, makes any warranty, express or implied, or assumes any legal liability or responsibility for the accuracy, completeness, or usefulness of any information, apparatus, product, or process disclosed, or represents that its use would not infringe privately owned rights. Reference herein to any specific commercial product, process, or service by trade name, trademark, manufacturer, or otherwise, does not necessarily constitute or imply its endorsement, recommendation, or favoring by the United States Government or the University of California. The views and opinions of authors expressed herein do not necessarily state or reflect those of the United States Government or the University of California, and shall not be used for advertising or product endorsement purposes.

This report has been reproduced directly from the best available copy.

Available to DOE and DOE contractors from the Office of Scientific and Technical Information

P.O. Box 62, Oak Ridge, TN 37831

Prices available from (615) 576-8401, FTS 626-8401

Available to the public from the

National Technical Information Service

U.S. Department of Commerce

5285 Port Royal Rd.,

Springfield, VA 22161 


\title{
Degradation Mode Survey \\ Galvanic Corrosion of Candidate Metallic Materials for High-Level Radioactive Waste Disposal Containers
}

\author{
by
}

A. K. Roy

D. A. Jones

R. D. McCright

August 26, 1996 


\section{Table of Contents}

1. Background

2. Fundamentals of Galvanic Corrosion

2.1 Galvanic Series

2.2 Mixed-Potential Theory

2.3 Factors Influencing Galvanic Corrosion

3. Experimental Techniques

3.1 Electrochemical Tests

3.1.1 Polarization in Galvanic Couples

3.1.2 Zero Resistance Ammeters

3.1.3 Galvanic Current Diagrams

3.1.4 Current and Potential Distributions

3.2 Exposure Tests

4. Candidate Container Materials

5. Galvanic Corrosion of Carbon and Low-Alloy Steels

6. Galvanic Corrosion of $\mathrm{Cu}-\mathrm{Ni}$ and Ni-Cu Alloys

7. Galvanic Corrosion of Stainless Steels

8. Galvanic Corrosion of High-Ni and Ni-Base Alloys

9. Galvanic Corrosion of Titanium and its Alloys

10. Galvanic Corrosion of Welded Joints

11. Summary

Acknowledgement

References

Tables

Figures 


\section{Degradation Mode Survey \\ Galvanic Corrosion of Candidate Metallic Materials \\ for High-Level Radioactive Waste Disposal Containers}

\section{Background}

The current high-level nuclear waste package design effort is focused on all-metallic multibarrier concepts to accommodate canistered spent fuel, uncanistered spent fuel, and defense high-level waste glass canisters. This design incorporates an outer corrosionallowance metal barrier over an inner container made of corrosion-resistant metal. The corrosion-allowance barrier, which will be thicker than the inner corrosion-resistant barrier, is being designed to undergo environment-induced degradation at a very slow rate, thus providing the inner container protection from the potential repository environment for a prolonged service period.

The method of fabricating these multi-barrier waste packages is yet to be finalized. Several options are currently being considered. One approach is to fabricate the two metallic barriers separately, and then slip the inner barrier into the outer. Under this scenario, assuming that the outer container has breached, crevice corrosion may occur between the two containment barriers during horizontal emplacement within the potential repository. Crevice corrosion can be prevented, however, by maintaining a larger gap between the inner and outer barriers by placing a spacer made of conductive material in between them. The outer corrosion-allowance container material will be selected to be more electronegative (active) and will undergo preferential galvanic corrosion, thus protecting the more noble inner barrier material.

A second option in fabricating the waste packages is to use clad or weld-overlayed materials. In this case, the outer corrosion-allowance barrier will have a thin layer of corrosion-resistant clad material inside, thus eliminating the gap between the two barriers while still providing galvanic protection to the more noble inner material. Waste packages made of clad materials may be prohibitively expensive. Therefore, more recently, shrinkfit waste packages are also being considered. Bonding between two containers will be achieved by contraction of the heated outer barrier material as it cools, and fits on the outside diameter of the inner barrier. However, this approach cannot ensure that the two dissimilar materials will be bonded totally to avoid the possibility of crevice corrosion resulting from solutions entrapped between the containment barrier layers.

Accumulated ferric corrosion products around the waste packages from the outer corrosion-allowance carbon steel barriers may induce localized corrosion including pitting and stress corrosion cracking (SCC) of the inner corrosion-resistant container material, if breaching occurs. The ferric/ferrous redox couple is a strong oxidizer which can raise corrosion potential above pitting and crevice initiation potentials of the corrosion-resistant alloys. SCC has been observed even at room temperature in austenitic stainless steels in the presence of concentrated chlorides and strong oxidizers ${ }^{(1,2)}$. Certainly, chloride-rich 
solutions are likely to develop as chloride-containing groundwaters boil and evaporate around the containers.

In light of the preceding discussion, it appears that both localized corrosion, such as pitting corrosion, crevice attack, SCC, and galvanic corrosion will be important modes of degradation in waste package container materials. Degradation mode surveys on localized corrosion including pitting corrosion, crevice corrosion and SCC of candidate materials have been previously reported ${ }^{(3)}$. This report will present the results of a literature review on galvanic corrosion between candidate metals and alloys currently being considered for the waste package containers.

\section{Fundamentals of Galvanic Corrosion}

Galvanic corrosion is accelerated corrosion of a metal or an alloy caused by electrical contact with a more noble conducting material while exposed to a corrosive electrolyte. A galvanic current flows between two dissimilar metals electrically coupled in the same electrolyte. The material showing a more negative (or active) corrosion potential acts as the anode, and the direction of current flow will be from the anode to the cathode, the metal with the more positive (or noble) corrosion potential. Consequently, corrosion of the anodic material will be enhanced and attack at the cathodic material will be reduced, as described below. In some rare cases, however, galvanic coupling may beneficially passivate the anode as described later for titanium coupled to noble metals.

\subsection{Galvanic Series}

The mixed potential theory, proposed by Wagner and Traud ${ }^{(4)}$, is based on two simple hypotheses. First, any electrochemical reaction can be divided into two or more oxidation or reduction reactions, and second, there can be no net accumulation of electrical charge during an electrochemical reaction. Each metal and alloy has a steady-state, or uncoupled, potential in a given environment, versus a standard reference electrode. At this potential, a corrosion current density can be measured, which, can be directly converted to a corrosion rate.

An oxidation or anodic reaction is indicated by an increase in valence or a production of electrons. A decrease in valence charge or the consumption of electrons signifies a reduction or cathodic reaction. The potential at which the rate of oxidation equals the rate of reduction is called the open-circuit or corrosion potential, $\mathrm{E}_{\text {corr. }}$ The rate at which this equilibrium occurs is called the corrosion rate, $\mathrm{i}_{\text {corr }}$. The process of changing potential from $E_{\text {corr }}$ by applying an external current is called polarization.

When any two different alloys are coupled together, the one with the more negative or active corrosion potential loses electrons to the more positive or noble one. In a couple 
between the two metals, $\mathrm{M}$ and $\mathrm{N}$, the loss of electrons increases the anodic dissolution or corrosion rate,

$$
\mathrm{M} \rightarrow \mathrm{M}^{\mathrm{n}+}+\mathrm{ne}^{-}
$$

of the active metal, $M$, which thus becomes the anode in the galvanic cell. The more positive alloy, $\mathrm{N}$, has the rate of its anodic reaction,

$$
\mathrm{N} \rightarrow \mathrm{N}^{+}+\mathrm{me}^{-},
$$

decreased due to the excess of electrons drawn from $\mathrm{M}$. N is the cathode of the galvanic cell, and the corrosion rate decrease is the basis of cathodic protection by a sacrificial anodic alloy such as $M ; m$ and $n$ are integers denoting the number of electrons exchanged in the respective reactions.

The Galvanic Series is a list of corrosion potentials, measured in real or simulated service conditions, for various engineering alloys and pure metals. Figure $1^{(5)}$ shows the measured corrosion-potential range for each alloy. The most active (negative) alloy in a couple is always attacked preferentially by galvanic corrosion. Selection of alloys with a minimum potential difference will minimize corrosion in galvanic couples.

The Galvanic Series gives only the potential difference between uncoupled anode and cathode in the galvanic cell; it gives no information about the rate of galvanic corrosion. The series for aerated sea water in Figure 1 is sometimes assumed to be the same or similar for other environments, a practice that should be used only with caution. Changes in electrolyte composition and temperature can produce significant changes in potential positioning in the Galvanic Series. Each major change in environmental conditions requires that a new series be established. Thus the Galvanic Series gives qualitative indications of the likelihood of galvanic corrosion, but quantitative predictions are impossible. Quantitative rates can be predicted from polarization diagrams obtained through use of mixed-potential theory, and from results of exposure testing described below.

\subsection{Mired-Potential Theory}

The galvanic current between two dissimilar metals or alloys in an aqueous environment polarizes their respective surfaces as anode and cathode just as would be supplied by external instrumentation. The solid lines in Figure 2 show schematic experimental polarization curves in a galvanic couple. The dashed lines represent the polarization curves for the half cell reactions defining the uncoupled corrosion potentials, $\mathrm{E}_{\mathrm{corr}}, \mathrm{A}$, and $E_{c o r r}, C$, for anode and cathode, $M$ and $N$, respectively. The couple potential, $E_{\text {couple, is }}$ established where anode and cathode are polarized to equal potentials by the same current, Icouple, as discussed previously. Reduction reactions on the anode metal are assumed to 
be very small compared to such reactions on the cathode, shown in Figure 2. That is, $I_{\text {couple }} \gg I_{\text {corr, }} A$. The assumption is good for most practical galvanic couples.

The current flowing in a galvanic couple measures the anode dissolution and mass rate of galvanic attack. Galvanic current divided by the anode area gives the anode current density which is proportional to average corrosion or penetration rate. Some knowledge of current distribution on the anode is vital to predict the rate of galvanic corrosion at any given point on the anode.

When $\mathrm{M}$ and $\mathrm{N}$ are coupled or electrically connected together, electrons flow from $\mathrm{M}$ with the more negative $\mathrm{E}_{\text {corr }}$ to $\mathrm{N}$ with a more positive $\mathrm{E}_{\text {corr. }}$. The current from galvanic coupling causes polarization at the $M$ and $N$ surfaces just as if supplied from an external source. Electrons flowing from $M$ (anodic current) causes anodic polarization of the $M$ dissolution reaction. The same electrons entering $\mathrm{N}$ (cathodic current) cathodically polarize the hydrogen reduction reaction

$$
2 \mathrm{H}^{+}+2 \mathrm{e} \rightarrow \mathrm{H}_{2}
$$

The two surfaces polarize until they reach the same potential, $E_{\text {couple, }}$ where the total reduction current must equal the total oxidation current ${ }^{(6)}$. The galvanic current, Icouple, flowing at steady state is exactly analogous to the icorr between half cell reactions at the mixed potential on the surface of a single corroding metal.

Current rather than current density must be used in polarization diagrams of galvanic couples in this and following sections. The anodic current at the alloy anode must be divided by anode area to obtain current density which is proportional to penetration rate.

In galvanic couples involving two corroding metals, the potential of the couple always falls between the uncoupled corrosion potentials of the two metals. The corrosion rate of the metal with the more active corrosion potential, the anode, is always increased while the corrosion rate of the one with the more noble corrosion potential, the cathode, is always decreased. Decreased corrosion of the cathode at the expense of increased anode corrosion is the basis for cathodic protection by sacrificial anodes.

\subsection{Factors Influencing Galvanic Corrosion}

Any factor that affects corrosion of a single metal may also control galvanic corrosion involving two or more dissimilar conducting materials. Besides flow rate and $\mathrm{pH}$, these factors include temperature, electrolytic composition, surface condition of the metals, thermomechanical history of the surfaces, and many more too numerous to mention. Factors such as anode/cathode area ratio, distance between electrically connected materials, and geometric shapes are unique to galvanic corrosion behavior of many different metals and alloys. Area effects involve the ratio of the surface area of the more noble to the more active member. An unfavorable area ratio exists when the surface area 
of the cathodic member is larger compared to that of the anodic one. Under this condition, the anodic current density on the more active material will be extremely large, thus, leading to more pronounced galvanic attack. On the other hand, large anodic surface area and smaller noble member surface produces only slightly accelerated galvanic effects because of enhanced polarization of the cathodic member.

As to the effect of distance, dissimilar materials, galvanically coupled in close proximity, usually suffer greater from galvanic corrosion than those that are separated by larger gaps. The distance effect is dependent on solution conductivity since the path of current flow is the primary consideration. With respect to the geometry effect, galvanic current will not readily flow around comers since the current takes the path of least resistance.

\section{Experimental Techniques}

Laboratory tests to evaluate galvanic corrosion susceptibility of metallic materials fall into two categories: electrochemical tests, and exposure tests, which may or may not be monitored electrochemically.

\subsection{Electrochemical Tests}

Electrochemical techniques for evaluating galvanic corrosion are based on mixed-potential theory. These include potential measurements, current measurements, and polarization measurements. These techniques have been used successfully in various applications; however, caution must be exercised not to depend exclusively on one technique for all circumstances.

\subsubsection{Polarization in Galvanic Couples}

Conventional apparatus and methods can be used to measure polarization in galvanic couples directly with minor modifications. Anodic and cathodic polarization curves determined individually by appropriate current (galvanostatic) or potential (potentiostatic) control methods can be combined in polarization diagrams like Figure 2 to find the rates of galvanic corrosion. Individual experimental polarization curves of anode and cathode thus provide a reasonable prediction of polarization in the corresponding galvanic couple.

\subsubsection{Zero Resistance Ammeters}

The couple current is found at the intersection of the anodic and cathodic polarization curves where potentials of anode and cathode are equal (Figure 2). Anode and cathode potentials are also equal in a shorted galvanic couple with no intermediate instrumentation. Therefore, $I_{\text {couple }}$ in Figure 2 is the current in a shorted galvanic couple. A simple ammeter separates anode and cathode potentials by $\mathbb{R}_{\mathbf{m}}$ drop across the ammeter, where

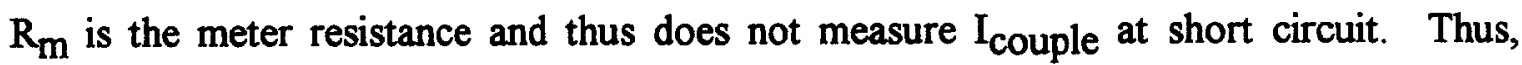


anode and cathode potentials are separated by $\mathbb{I}_{\mathrm{m}}$, and $\mathrm{I}$ is less than the desired $\mathrm{I}_{\text {couple, }}$ as indicated in Figure 3.

The circuit of Figure $4^{(7)}$ serves in effect as a zero resistance ammeter (ZRA) because the instrumentation can adjust current so that there is no resistance between anode and cathode. The power supply compensates for the usual $\mathbf{I R}_{\mathbf{m}}$ ohmic loss, and $I_{\text {couple }}$ is measured where the potential difference between anode and cathode is zero. A high impedance voltmeter is adequate to monitor the potential difference between anode and cathode in a simple ZRA. The reference electrode in Figure 4 is useful to obtain the polarization curves of Figure 2.

The galvanostatic ZRA of Figure 4 is useful for periodic measurements of $I_{\text {couple }}$ in a galvanic couple. However, it cannot be used to record couple current continuously. The polarization behavior of both anode and cathode usually vary with time along with the couple current. Thus, continuous adjustments to change the measured current are necessary to maintain anode and cathode potential difference at zero. Conversely, a potentiostat can be incorporated into a circuit to measure $I_{\text {couple continuously and }}$ automatically ${ }^{(8)}$. The potentiostat senses a difference between the REF and WE terminals of the instrument and controls the difference at a preset value by automatically varying the current between the WE and AUX terminals. When AUX and REF terminals are shorted, as shown in Figure 5, the potentiostat will control potential between anode $A$ and cathode $\mathrm{C}$ at any specified value. If that value is set at zero, the circuit will continuously and automatically read the $I_{\text {couple }}$ at short circuit on the milliammeter, $\mathrm{mA}$. Figure 6 shows continuous recording of short circuit current with time as affected by dichromate inhibitor additions $^{(8)}$.

\subsubsection{Galvanic Current Diagrams}

Galvanic current density ( $\mathrm{I}_{\text {couple }}$ divided by anode area) at the anode measures the rate of galvanic attack at the anode. The current density at any given point on the anode in turn depends on polarization of both anode and cathode, conductivity of the solution, and physical geometry of the couple, including the cathode/anode surface area ratio. The usefulness of anodic and cathodic polarization curves to visualize polarization within a galvanic couple was demonstrated in Figure 2. The polarization curves in Figure 2 can be obtained simultaneously in a single experiment. However, electrochemical polarization is not dependent on the source of polarizing current as long as current distribution is uniform. Thus the experimental polarization curves for anode and cathode may be measured independently by the conventional galvanostatic and potentiostatic methods and used to predict the galvanic current in a galvanic couple with uniform current distribution.

Bennett and Greene ${ }^{(9)}$ were the first to suggest a composite polarization diagram to predict current in galvanic couples. The diagram consists of anodic and cathodic polarization curves for numerous alloys in a particular solution electrolyte. Figures 7 and 8 show their collection of polarization curves for this purpose, measured in aerated $3 \%$ 
$\mathrm{NaCl}$ and deaerated 1-N sulfuric acid, respectively ${ }^{(10)}$. The corrosion potentials on the vertical axis constitute the galvanic series for the listed alloys in each environment. The polarization curves add a dimension of current or reaction rate to the galvanic series.

Polarization curves from Figures 7 and 8 for any pair of alloys can be used to predict the galvanic current passing when equal $1-\mathrm{cm}^{2}$ areas of the two are galvanically coupled. For example, the galvanic current in an iron-nickel couple is approximately $70 \mu \mathrm{A}$ using the polarization curves in Figure 9, taken from Figure 7. The vertical dashed lines represent the spread of values for the limiting current for reduction of dissolved oxygen which is essentially the same for all alloys displayed in Figure 8. The anodic current density is directly proportional to the penetration rate assuming that the current distribution is uniform. Figure 10 shows the galvanic behavior between the two alloys in sulfuric acid, taking the polarizations curves from Figure 8 . $I_{\text {couple }}$ increases about $25 x$ from Figures 9 to 10 , due to the change of environment which approximately corresponds to the the increased aggressiveness resulting from boiling and solute concentration expected in Yucca Mountain groundwaters near waste-container surfaces.

The effects of surface area ratio in sulfuric acid can be predicted by graphically adjusting the cathode currents in Figure 8, as shown in Figure 11. The galvanic current increases progressively as the Ni:Fe surface area ratio increases from 0.1 to 1.0 to 10 . Since the anode surface area has remained at $1-\mathrm{cm}^{2}$, the anodic current density increases correspondingly. Cathodic current density at the nickel remains constant because the cathode surface area has been increased proportional to the increased galvanic current.

Polarization data, taken in laboratory purity electrolytes in short times compared to service exposure times, may not give a reasonable measure of service performance. Over long periods of time and in the presence of undetermined impurities, corroding alloys can be expected to form surface conditions which cannot be predicted from short term laboratory electrochemical testing. Nevertheless, galvanic current diagrams offer useful guidelines and confirm known galvanic effects. Hack and Scully ${ }^{(11)}$ have shown that polarization curves on preexposed electrodes at very low scan rates give improved correlation with galvanic behavior in long term seawater exposures.

\subsubsection{Current and Potential Distributions}

Many useful predictions can be made assuming uniform current distribution, but most galvanic couples in practice do not conform to such an ideal. Quantitative predictions of galvanic corrosion often require further considerations of current and potential distribution on the surface of the anode.

The current and potential distributions between two galvanically coupled dissimilar metals depend on the conductivity of the electrolyte and the physical geometry of the couple, as well as polarization of anode and cathode. The effect of electrolyte or solution conductivity is similar to that of meter resistance $R_{m}$ in Figure 3. The effective solution 
resistance, $\mathbf{R}_{\boldsymbol{Q}}$, between any pair of points on an anode and a cathode separates the potential between those points by an amount $\mathbb{I R}_{\Omega}$ with a galvanic current $I<I_{\text {couple }}$ flowing in the couple.

The early data of Copson ${ }^{(12)}$ in Figure 12 illustrates the potential distribution in a coplanar couple between steel (iron) and nickel exposed for several weeks in aerated tap water. Potential was measured as a function of position in the electrolyte between a stationary reference electrode near the steel surface remote from the junction and an identical movable reference electrode. Lines of constant potential are shown on a plane perpendicular to the linear junction between the two metals. The tap water electrolyte is of relatively low conductivity, creating substantial ohmic losses between remote points on the two metals. The nickel cathode is highly polarized whereas the steel anode has very low polarization. As a result, the nickel cathode potential is affected by lower currents at a much greater distance from the junction as compared to the steel anode.

Strong concentration polarization is typical of the oxygen reduction reaction and largely independent of the metal surface because the limiting diffusion currents are the same for all. The low anodic polarization on the steel anode concentrates anodic current near the junction, and the attack decreases to the background or self corrosion rate characteristic of the environment at points remote from the junction. Lower solution conductivity and lower polarization generally concentrate galvanic attack nearer the junction in a galvanic couple ${ }^{(13)}$. Thus galvanic attack is increased further by galvanic-current concentration near the contact line between dissimilar metals due to the usual lower polarization of anode as compared to cathode.

Mathematical analysis of current and potential distributions in galvanic cells has been conducted for simplified geometries and polarization functions ${ }^{(13,14)}$. However, more complex systems have remained intractable until recently, when modern finite element ${ }^{(15)}$ and boundary element ${ }^{(16)}$ methods have been applied. Current and potential distributions on cathode structures are also of great practical importance on a larger physical scale in cathodic protection system using sacrificial anodes and impressed currents. Modeling will be useful to predict the cathodic protection afforded to the inner corrosion resistant alloy as the outer corrosion allowance layer is penetrated and dissolved away.

\subsection{Exposure Tests}

The most obvious method of testing for galvanic corrosion is to construct a couple between the materials of interest and place it in the environment of interest. Material condition, environment, and geometry should simulate the application as closely as possible. The different materials can either be placed in physical contact to provide electrical connection or can be wired together so that the current between them can be monitored, as a function of time. Ensuring adequate electrical contact between the two dissimilar materials in a galvanic couple may, however, be very difficult. Pressure contact, such as between two plates bolted together, is subject to corrosion products forming between the plates and wedging them apart. Attachment of wires by soldering or brazing 
will work with some materials, but the use of drilled and tapped holes for screw attachment may be needed for others. Whatever connection method is used, the connection area and wire are subject to corrosion, which can affect both the electrical contact and the performance of the galvanic couple being tested. For this reason, coatings are frequently used on the connection area. Also, the duration of exposure is important in galvanic corrosion testing. In many galvanic couples, the extent of degradation is highly variable with time. More details on galvanic corrosion testing are provided in ASTM Designation G 71 entitled "Guide for Conducting and Evaluating Galvanic Corrosion Tests in Electrolytes,".

Quantitative galvanic corrosion rates can be evaluated by simultaneous immersion of two dissimilar materials, uncoupled and coupled, in a common electrolytic environment for a specific duration. Corrosion rate of these materials, under both conditions, can be determined from the weight-loss data. It is anticipated that the extent of corrosion of the more active material will be increased and attack at the more noble material will be reduced due to galvanic coupling, as compared to their uncoupled corrosion behavior.

\section{Candidate Container Materials}

Materials currently being considered for fabricating waste package containers can be broadly classified into three categories. They are: corrosion-allowance materials, moderately corrosion-resistant materials, and highly corrosion-resistant materials. Carbon and low-alloy steels, such as 1020 carbon steel (ASTM A 516), and 2.25Cr-1Mo steel (ASTM A 387), respectively, which fall under the first category, are the candidate materials for the outer barriers. Under a high thermal load scenario, these corrosionallowance barriers will be subjected to relatively warm and dry air initially which will change to cooler and somewhat moister air over time. For a low thermal load, these barriers will experience relatively cool and moist air for most of the containment periods. For this condition, consideration should be given to the impact of microbiologicallyinfluenced corrosion (MIC) of the outer barriers. Accordingly, some moderately corrosion-resistant materials, such as the 70/30 Cupronickel (CDA 715) and nickel-copper (Ni-Cu) Alloy 400, are also being considered as outer container materials in view of their superior MIC resistance. Furthermore, these alloys may minimize leaching of vitrified defense high-level waste contained in stainless steel canisters.

Highly corrosion-resistant materials, under consideration for the inner container, are Alloys 825, G-3, G-30, 625, C-4 and C-22, and titanium-base alloy Ti GT-12. Of these materials, Alloys 825, G-3 and G-30 are iron-nickel-chromium-molybdenum (Fe-Ni-CrMo) alloys. Alloys G-3 and G-30 are comparable in composition to Alloy 825, but have somewhat higher alloy content for enhanced resistance to localized attack such as pitting corrosion. Alloys $625, \mathrm{C}-4$ and $\mathrm{C}-22$, all Ni-Cr-Mo alloys, have been identified by the Lawrence Livermore National Laboratory (LLNL) as alternative metallic materials for the inner container because of their high-temperature stability and superior overall corrosion resistance compared to other Ni-Cr-Mo alloys available today. Ti Gr-12 has been considered in view of its outstanding corrosion resistance, and its useful combination of 
low density and high strength. The nominal composition of materials under all three categories are shown in Table 1.

\section{Galvanic Corrosion of Carbon and Low-Alloy Steels}

Numerous studies ${ }^{(17-24)}$ on the corrosion behavior of carbon and low-alloy steels coupled to other materials while exposed to various environments have been reported. An extensive study was conducted by Johnson and Abbott ${ }^{(17)}$ to evaluate the galvanic corrosion behavior of mild steel coupled to many dissimilar materials, and exposed to a range of different natural environments including industrial, urban/rural, marine, natural water, and seawater. Disc-shaped specimens were used to determine the corrosion rates of various combinations of metallic couples. Equal anodic and cathodic areas were used, and intimate contact was maintained between the surface areas. All specimens were weighed prior to their assembly into the test couples. Test duration ranged between 272 and 578 days. Upon completion of testing, the couples were dismantled, and the corrosion rates were determined from the weight-loss of the chemically-cleaned specimens. Corrosion rates for each metal of a given couple at each test site are shown in Tables 2 through 6.

Several investigators ${ }^{(18-20)}$ have studied the effect of anode/cathode area ratio on corrosion susceptibility of carbon steels galvanically coupled to more noble materials in aqueous environments containing sodium chloride $(\mathrm{NaCl})$. The importance of area ratio on the corrosion rate of carbon steel exposed to seawater ${ }^{(18)}$ for 174 days is illustrated in Table 7. This study found that the average penetration of uncoupled structural carbon steel in marine environment was around 36 mils following two years of exposure. However, coupling this carbon steel to a stainless steel specimen of equal area doubled its corrosion rate. Moreover, coupling to a stainless steel area eight times that of the carbon steel resulted in a corrosion rate for the carbon steel that is about eight to nine times that of the uncoupled steel. The reason for these increases is that the rate of corrosion of the carbon steel is determined by the rate of diffusion of oxygen to its cathodic areas. Coupling to a more noble material such as stainless steel increases the effective cathodic area by the area ratio of the two metals, and therefore, the corrosion rate would be expected to increase proportionally. Conversely, the galvanic attack on the carbon steel will be moderate when its surface area becomes relatively larger compared to that of the stainless steel, as shown by the corrosion rate data in Table 7.

The results of a similar study ${ }^{(19)}$ conducted in synthetic seawater at ambient temperature indicate (Table 8 ) that the corrosion rate of mild steel increases considerably when coupled to equal areas of more noble metals and alloys that are commonly used in seawater systems. The difference in rates depends on the electrochemical characteristics of the corresponding noble metal with respect to the cathodic reaction. A similar effect of area ratio on corrosion susceptibility has been demonstrated in the same investigation. The combined effect of $\mathrm{NaCl}$ concentration and area ratio on the corrosion rate of mild steel coupled to platinum has also been reported ${ }^{(20)}$. The relationship between the 
corrosion rate and $\mathrm{NaCl}$ concentration in neutral solutions at various area ratios is shown in Figure 13. It is clear from this data that the maximum corrosion rate occurs at about $1 \% \mathrm{NaCl}$. This phenomenon becomes more conspicuous as the cathode to anode area ratio $\left(A_{c} / A_{a}\right)$ increases.

Kirk et al. ${ }^{(21)}$ evaluated the galvanic corrosion behavior of high-strength low-alloy steels such as HY 80 and 4340 steels coupled to equal areas of $12 \% \mathrm{Ni}-5 \% \mathrm{Cr}-3 \% \mathrm{Mo}$ Maraging steel in flowing seawater. The results indicate that the uncoupled Maraging steel and low- alloy steel specimens underwent corrosion in a normal manner. However, when coupled, the corrosion rate of Maraging steel was reduced to negligible values. Another short-term study ${ }^{(22)}$ involving galvanic couples of 4130 steel and titanium in seawater revealed that titanium was highly corrosion-resistant in that it was not influenced by its contact with the steel.

A comprehensive longer-term corrosion study involving fifty-two different materials in five distinct tropical environments namely, sea and fresh water immersion, seawater mean tide, and coastal and inland atmospheres, has been reported by Southwell et al ${ }^{(23)}$. Generally, equal areas of disc-shaped specimens (single and bimetallic) were exposed simultaneously in different environments. Carbon steel was attached to most of the other materials in bimetallic couples. Data suggest that carbon steel is a highly effective anodic metal for protecting more noble metals and alloys such as stainless steel and $\mathrm{Ni}-\mathrm{Cu}$ alloys in seawater. The highest corrosion rate for carbon steel was observed when it was coupled to pure copper. In the fresh lake water, there was a lesser but still definite galvanic effect. Cathodic protection of more noble metals with carbon steel was usually less effective in this environment, but corrosion of smaller-area anodic materials was sometimes found to be accelerated considerably. In atmospheric exposures, the tropical coastal atmosphere generally caused about four to eight times as much galvanic corrosion compared to that in the tropical inland atmosphere.

Bimetallic corrosion of structural material such as carbon steel due to exposure in various types of atmosphere including rural, marine, unban, and industrial, has also been investigated by Kucera and Mattsson $^{(24)}$. Although the principle of galvanic corrosion is very similar both in aqueous solutions and in atmosphere, one important feature of galvanic atmospheric corrosion is that it proceeds in thin films of electrolyte on the metal surface. The thinner the moisture film on the metal surface, the narrower the range of attack at the bimetallic contact. In general, atmospheric pollutants, such as sulfur compounds or sodium chloride, will increase the conductivity of the moisture film on the metal surface, and, thus, favor galvanic corrosion. When carbon steel is coupled to less noble metals, it acts as a very efficient cathodic material by virtue of the rust formation on its surface. Compared to corrosion products formed on more noble metals, rust formed on carbon steel is voluminous and, thus, can absorb atmospheric pollutants and moisture. 


\section{Galvanic Corrosion of $\mathrm{Cu}-\mathrm{Ni}$ and Ni-Cu Alloys}

Several studies ${ }^{(25-27)}$ have been carried out on galvanic corrosion of copper $(\mathrm{Cu})$ and nickel (Ni) alloys coupled with other materials in seawater. Cu-alloys are almost always cathodic to other common structural metals such as carbon steel, low-alloy steel, and aluminum. The common grades of stainless steel exhibit variable behavior; that is, copper alloys may be either anodic or cathodic to the stainless steel, depending on the conditions of exposure. $\mathrm{Cu}$-alloys usually undergo preferential corrosion when coupled to high-Ni alloys and titanium (Ti). Galvanic coupling between two different $\mathrm{Cu}$-alloys does not cause any problem, since the potential difference is very small. Kunieda et al. ${ }^{(28)}$ studied the effects of dissolved oxygen concentration, $\mathrm{pH}$, temperature, flow rate and the area ratio on the galvanic corrosion of $\mathrm{Cu}-\mathrm{Ni}$ alloy $(90 / 10 \mathrm{Cu}-\mathrm{Ni})$ coupled to $\mathrm{Ti}$ in seawater. Results indicate that the corrosion rate of the $\mathrm{Cu}-\mathrm{Ni}$ alloy was increased ten times with the lowering of $\mathrm{pH}$ from 8 to 6 . The extent of galvanic corrosion was found to be enhanced due to increased dissolved oxygen concentration, and increase in the area ratio of Ti to $\mathrm{Cu}-\mathrm{Ni}$ alloy. Furthermore, increasing flow rate increased the corrosion rate of the anodic material because of increased speed of supplying oxygen to the metal surface and removing protective corrosion products. The effect of flow rate on the corrosion behavior of galvanic couples (70/30 Cu-Ni / carbon steel, and Monel 400 / carbon steel) in synthetic seawater has been reported in another study ${ }^{(29)}$. The results indicate that Monel 400 polarizes more quickly in stagnant environment than does $70 / 30 \mathrm{Cu}-\mathrm{Ni}$, thus reducing the corrosion rate of the anodic material. Consistent with other investigations, the corrosion rates for both couples were observed to be enhanced with increasing flow rate.

The results of galvanic corrosion study involving Cu-Ni alloys (70/30 and 90/10 Cu-Ni) and Monel $400(70 / 30 \mathrm{Ni}-\mathrm{Cu})$, while coupled with highly-alloyed $254 \mathrm{SMO}$ (Fe-Ni-CrMo) steel in seawater, have been reported by Wallen and Andersson ${ }^{(30)}$. Their data indicate that all three materials were preferentially attacked due to coupling to the stainless steel at 1:1 area ratio. Coupling these alloys to Ti resulted in similar or slightly lower corrosion rates. One interesting observation was that both 254 SMO stainless steel and Monel 400 suffered from crevice corrosion when the former metal was coupled to Monel 400 at an area ratio of 11:1. Southwell and Alexander ${ }^{(31)}$ reported the results of their investigation using carbon-steel anodes for protecting larger areas of 70/30 $\mathrm{Cu}-\mathrm{Ni}$ and Monel 400 in seawater environment. At the anode/cathode area ratio of 1 to 6.9 , the $\mathrm{Cu}$ $\mathrm{Ni}$ alloy was almost completely protected during 8 years' exposure, at the end of which the carbon-steel anodes were depleted and the corrosion of the $\mathrm{Cu}-\mathrm{Ni}$ alloy continued at its normal rate. Monel $\mathbf{4 0 0}$ was equally protected, and the steel anodes lasted for more than eight years. Corrosion rates due to weight loss in both alloys were insignificant, showing no crevice or underfouling corrosion.

A limited number of studies have been reported ${ }^{(32-33)}$ on the corrosion behavior of stainless steels, galvanically coupled to commercially available pure copper. Baboian et al. ${ }^{\text {(32) }}$ evaluated the corrosion behavior of copper-clad Types 409, 430 and 321 stainless steel 
laminates subjected to marine atmosphere. Two types of corrosion was observed; uniform corrosion of copper cladding with no galvanic corrosion of the stainless steel substrate, and uniform corrosion of copper cladding with galvanic pitting and tunneling of the substrate. The observed type of corrosion was found to be a function of the environment and the composition of the stainless steel. The attack observed on copper-clad Types 409 and 430 stainless steel laminates were attributed to galvanically-induced localized breakdown of the protective film on the stainless steels in marine environments. Localized breakdown of the passive film on these materials in chloride-containing aqueous media has been explained by electrochemical polarization measurements ${ }^{(33,34)}$. On the other hand, while all three types of stainless steel suffered from pitting corrosion in the monolithic state in marine environment, localized attack was not observed in the copper-clad Type 321 stainless steel laminate. As to the corrosion rate of the copper cladding, it was very similar to that of the monolithic copper. The beneficial effect of copper in minimizing underground corrosion of highly-alloyed stainless steels through galvanic coupling has also been reported elsewhere ${ }^{(33)}$.

\section{Galvanic Corrosion of Stainless Steels}

Caplan ${ }^{(36)}$ investigated the galvanic corrosion behavior of manganese-substituted austenitic Nitronic 50 stainless steel coupled to mild steel (HY-80), 90/10 Cu-Ni, 70/30 Cu-Ni, Monel 400, austenitic Type 304 stainless steel, martensitic17-4 PH stainless steel, Inconel 625 and Ti-621 alloy in flowing seawater for thirty days. Measured mixed-potential, current flow for each couple, and the corrosion rates are shown in Table 9. None of the Nitronic 50 samples experienced any measurable weight loss even though slight crevice corrosion tendency was observed in some specimens. In contrast, the other stainless steels (Type 304 and 17-4 PH) suffered from substantial corrosion damage. The HY 80 steels and Cu-base alloys showed large weight losses. In case of Monel 400 , massive but shallow pitting attack was observed. Both the corrosion rate and galvanic current for this $\mathrm{Ni}-\mathrm{Cu}$ alloy were very low, suggesting that this material may be compatible with Nitronic 50 in terms of galvanic protection. As to the performance of Inconel and Ti couples, none of them showed any sign of surface degradation, with the Ti couple undergoing a slight weight loss. The galvanic current measured between these two noble materials and Nitronic 50 was essentially zero.

Galvanic corrosion behavior of Type 304 stainless steel coupled to iron-manganesealuminum alloys has been studied by $\mathrm{Gau}$ and $\mathrm{Wu}^{(37)}$ in artificial seawater at ambient temperature. Their results showed that Type 304 stainless steel acted as a cathode and experienced no corrosion. The effect of galvanic coupling on underground soil-corrosion at different U.S. locations has been evaluated by Escalante and Gerhold ${ }^{(38)}$. Stainless steels studied include metastable Type 301, austenitic Type 304, single-phase ferritic $26 \mathrm{Cr}-1 \mathrm{Mo}$, and austenitic-ferritic $26 \mathrm{Cr}-6.5 \mathrm{Ni}$, which were coupled to magnesium (Mg), zinc $(\mathrm{Zn})$, and iron (Fe). Results indicate that Type 301 stainless steel, coupled to $\mathrm{Mg}, \mathrm{Zn}$, and $\mathrm{Fe}$, underwent failure possibly by hydrogen embrittlement due to its higher strength resulting from martensite formation during the cold working operation. On the contrary, 
no failures were observed for galvanic couples involving the other three types of stainless steel, and $\mathrm{Mg}, \mathrm{Zn}$, and $\mathrm{Fe}$ under similar environmental conditions. These three stainless steels were used in the solution-annealed condition. It is important to mention that none of the uncoupled specimens failed, indicating their resistance to failure while at open circuit potential.

\section{Galvanic Corrosion of High-Ni and Ni-Base Alloys}

The effect of galvanic coupling on embrittlement of high strength $\mathrm{Ni}$-base alloys such as Alloys C-4 and C-276, Inconel 625, and Co-base MP35N has been investigated by Kane et al. ${ }^{(39)}$ in $\mathrm{H}_{2} \mathrm{~S}$-containing brines at ambient and elevated temperatures. Materials were tested in both unaged and aged conditions using uncoupled and Coupled (with Alloy $C$, and carbon steel nuts and bolts) C-ring specimens. The results indicate that no cracking occurred in any $\mathrm{C}$-ring specimens coupled with Alloy $\mathrm{C}$ nuts and bolts even at applied stress level of $100 \%$ of their transverse yield strength (YS) values. However, unaged Inconel 625, Alloy C-4, and MP35N C-rings coupled to carbon steel underwent failure at similar YS levels. Alloy C-276, which did not fail in the unaged and coupled (with steel) condition at an applied stress of $100 \%$ of transverse YS, failed at the same stress level when tested in an aged condition. No failures were observed in any longitudinally stressed specimens even under very severe testing conditions, or in transversely stressed specimens without steel couples. Thus, the cracking susceptibility of these high performance alloys appears to be dependent on galvanic interaction with carbon steel and sample orientation. No rational explanation can, however, be provided as to the deleterious effects of relatively low temperature aging on the resistance to embrittlement. The results also indicate that the elevated temperature $\left(300^{\circ} \mathrm{F}\right)$ environments were beneficial in that Alloy C-276, Inconel 625, and MP35N specimens did not undergo failure even when: (1) stressed to same YS levels, (2) aged, and (3) galvanically coupled with carbon steel nuts and bolts.

A study by Chouthai and Gadiyar ${ }^{(40)}$ indicate that when Ni-base materials are coupled to $\mathrm{Ti}$ in an acidic environment, the corrosion rate of $\mathrm{Ti}$ is increased and a slight reduction in corrosion rate occurred for Inconel. Duncan and Arney ${ }^{(41)}$ investigated the effect of galvanic coupling of phosphorus-containing $(9-11.5 \% \mathrm{P})$ electroless nickel with carbon steel in seawater. The results indicate that the corrosion rate of carbon steel was significantly increased when a connection was made to electroless nickel, implying that galvanic corrosion in seawater can be very severe for steels coupled to electroless nickel.

\section{Galvanic Corrosion of Titanium and its Alloys}

The galvanic corrosion behavior of $\mathrm{Ti}$, coupled to carbon steel, Type 304 stainless steel, Incoloy 800, Inconel 600, and Hastelloy $\mathrm{B}$ and $\mathrm{C}$ alloys in aqueous solutions containing $\left(\mathrm{NH}_{4}\right)_{2} \mathrm{~S}$, has been studied by Foroulis ${ }^{(42)}$. The data show that $\mathrm{Ti}$ was anodic by about 100 to $250 \mathrm{mV}$ with respect to all other tested materials. On the other hand, Ti became 
cathodic to other materials by about 20 to $300 \mathrm{mV}$ when cyanide and chloride ions were added to the sulfidic solutions. The observed reversal in galvanic polarity of $\mathrm{T} i$ in sulfidic solutions containing cyanide and chloride ions can possibly be attributed to the breakdown of protective sulfides, or other passive films on the tested materials by the cyanide or chloride ions, thus, causing active corrosion and more negative corrosion potential in carbon steel and other commonly used alloys. The beneficial effect of higher anode-tocathode area ratio on the corrosion rate of carbon steel coupled to $\mathrm{Ti}$ was also demonstrated in this investigation, as illustrated in Figure 14.

Shalaby ${ }^{(43)}$ evaluated the effect of galvanic coupling of $\mathrm{Ti}$ with $90 / 10 \mathrm{Cu}-\mathrm{Ni}$ alloy in chloride solutions at ambient temperature and $90^{\circ} \mathrm{C}$ under flowing conditions. The results indicate that the $\mathrm{Cu}-\mathrm{Ni}$ alloy was slightly attacked, and its contact with equal area of $\mathrm{Ti}$ did not lead to any appreciable increase in its corrosion rate. However, when a relatively larger area of $\mathrm{Ti}$ was used, $\mathrm{Cu}-\mathrm{Ni}$ alloy showed pitting corrosion in $90^{\circ} \mathrm{C}$ test. Generally speaking, Ti behaves as a noble metal and exhibits a cathodic potential when coupled to most other engineering materials. However, the possibility for enhanced corrosion by anodic dissolution of other metals must always be considered when coupling Ti to another metal in conducting media. For example, galvanic coupling of 70/30 Cu-Ni with $\mathrm{Ti}$ in seawater can substantially increase the corrosion rate of the $\mathrm{Cu}-\mathrm{Ni}$ alloy compared to that under the uncoupled condition ${ }^{(44,45)}$

Questions are often asked as to the corrosion behavior of Ti coupled to stainless steels. With stainless steels such as Types 304 and 316 that develop protective films, there is little difference in the electrochemical potential between these steels and Ti. This potential difference is very insignificant to initiate preferential attack of stainless steels ${ }^{(46,47)}$. However, other factors such as the presence of a crevice in the couple may produce much more negative potentials, leading to an electrolytic cell with high driving force. If these stainless steels possess increased concentration of $\mathrm{Cr}$ and Mo, the risk for initiation of localized attack such as pitting and crevice corrosion can be minimized, and these steels will become compatible to Ti and its alloys. Ti can be coupled to high performance Nirich and Ni-base alloys as well without producing any detrimental effect.

The corrosion resistance of $\mathrm{Ti}$ is largely due to the inert, tightly adherent oxide film that covers its surface. This film can, however, be damaged by iron particles embedded or smeared into the surface of Ti equipment from contact during fabrication. Iron can also be found in solution in many process streams, often as a contaminant from corrosion of iron or iron-base alloy components. Covington and Schutz ${ }^{(48)}$ investigated the effect of iron as metallic particles embedded into the $\mathrm{Ti}$ surface by measuring the potential difference between mild steel and unalloyed $\mathrm{Ti}$ immersed in a saturated salt solution at temperatures near its boiling point. Their study indicate that the measured potential difference was sufficient enough to establish an electrochemical cell in which the mild steel would be consumed as the anode. By the time the iron particles were consumed, pits were formed due to acidification, and rupture of the protective film, thus, causing continued corrosion 
of Ti surface. When iron is present in solution as ferric ions, it is beneficial ${ }^{(49)}$ to Ti in that its presence shifts the corrosion potential of $\mathrm{Ti}$ in the noble direction, thus making $\mathrm{Ti}$ more passive.

In dilute acid solutions, titanium corrodes at a high rate in the active state. When coupled to platinum, the corrosion rate of the titanium anode surprisingly decreases rather than increases as for iron in Figure 7 and 8 . This novel behavior is due to the passivation effects shown in Figure 15, which shows polarization curves for the $\mathrm{Ti}$ and $\mathrm{Ni}$ in deaerated 1-N sulfuric acid. Platinum increases the cathodic reduction of hydrogen to a level that stablizes the passive film. The reduction current is higher than the critical anodic current density for $\mathrm{Ti}$ passivation, $\mathrm{i}_{\mathrm{c}}$. In fact, the exchange current density for the hydrogen reaction on platinum, $\mathrm{i}_{\mathrm{O}}, \mathrm{H} 2(\mathrm{Pt})$ is so high that the potential is controlled essentially at the half cell potential for the hydrogen redox reaction. The corrosion rate for $\mathrm{Ti}$ is reduced to $\mathrm{i}_{\text {couple(Ti-Pt). }}$

The half cell potential of the oxidizer, e.g., $\mathrm{e}_{\mathrm{H} 2 / \mathrm{H}+}$ in Figure 15 , must be more noble than the primary passivation potential, $\mathrm{E}_{\mathrm{pp}}$, of the active-passive alloy. The exchange current density for the oxidizer reaction on the cathode must be very high also in order for the total reduction current to exceed $i_{c}$ at $E_{p p}$. These conditions are met only for titanium and chromium in air free acid solutions when coupled to noble metal cathodes such as platinum, palladium, rhodium and iridium ${ }^{(10)}$. However, Figure 15 shows that when coupled to titanium, nickel may also have the requisite properties for passivation.

Small amounts of noble metals alloyed with titanium successfully increase the corrosion resistance in hot acid solutions in which dissolved oxidizers such as oxygen have low solubility. Although not sufficient in bulk concentration, the alloying element enriches on the surface because it is essentially inert in the acid solutions. Soon there is enough surface area of the noble metal to facilitate passivation. If the enriched surface is abraded or otherwise damaged, the enrichment process repeats itself until the damaged area is again passivated. Commercial purity $\mathrm{Ti}$ with additions of 0.12 to $0.25 \% \mathrm{Pd}$ are commercially available and have maximum corrosion resistance to hot acid solutions and crevice corrosion. Less expensive $\mathrm{Ti}-\mathrm{Ni}$ alloys have met with considerable commercial success $^{(50)}$. Titanium, Code-12, contains optimally $0.8 \% \mathrm{Ni}$ and $0.3 \% \mathrm{Mo}$. Molybdenum reduces the critical current density needed for passivation ${ }^{(51)}$ and thereby the necessary amount of alloyed nickel.

\section{Galvanic Corrosion of Welded Joints}

Corrosion in welded joints is generally limited to either the weld metal or the heataffected-zone (HAZ) of the parent metal. The weld-metal corrosion, which has received a great deal of attention, is thought to be caused by electrochemical potential differences between weld metal and the parent metal. HAZ attack is very common with Types 304 and 316 stainless steels. When these materials are welded, in the areas adjacent to the weld, carbon is tied to $\mathrm{Cr}$ as carbides, thus, depleting $\mathrm{Cr}$ from the grain boundaries and 
causing preferential attack of this Cr-depleted region. Several studies have been reported $^{(52-54)}$ on the effects of chemical composition, welding temperature, and the resultant microstructure on HAZ corrosion of commercially-available carbon steels used in shipbuilding. The results indicate that the corrosion susceptibility of HAZs increased with manganese (Mn) content of these steels, but was probably far less dependent on the total carbon content. Raising the welding temperature or increasing the heat input reduced the corrosion risks markedly. These observations can be explained on the basis of the resulting microstructure in the HAZ. An increase in the Mn content affects the phases formed in the HAZ in the same manner as an increase in the cooling rate. When the heat input decreases or the Mn content in the parent metal increases, austenite will decompose at lower temperatures producing metastable microstructures containing upper bainite with retained austenite or martensite. These low-temperature decomposition products will contain a greater amount of lattice defects (such as dislocations and point defects) than an equi-axed ferritic-pearlitic microstructure formed at higher welding temperatures. These low-temperature microstructural constituents may assume anodic character under seawater conditions, which in turn can lead to the formation of micro-galvanic cells within the $\mathrm{HAZ}$ area.

McMinn and Page ${ }^{(55)}$ investigated the stress corrosion cracking (SCC) susceptibility of Alloy 600-A508 low alloy steel weldments in a simulated boiling water reactor environment at $288^{\circ} \mathrm{C}$ using Ni-based weld metals compatible with Alloy 600 . Their results indicate that the majority of the SCC failures occurred at the A508-weld metal fusion line, suggesting that this galvanic coupling might have shifted the electrochemical potential of the fusion line region into a critical range where SCC can occur. The galvanic corrosion behavior of the interface of various explosively-bonded metallic combinations in a marine environment has been studied by Lindsey and Vasanth ${ }^{(56)}$. This fabrication technique is capable of producing a crevice-free metallurgical weld between metals that otherwise cannot be welded. The results indicate that, compared to a traditional galvanic couple, the explosively-bonded couple generated a very negligible galvanic current that did not appreciably change with time. Furthermore, the galvanic potentials were fairly stable, suggesting that explosively-bonded materials may perform well in chloride/marine environments. Thus, it appears that when galvanic and crevice corrosion become major concerns, explosively-bonded materials might be an attractive alternative.

\section{Summary}

A literature survey on galvanic corrosion behavior of different candidate corrosionallowance and corrosion-resistant metallic container materials in various environments is presented in this report. Alloys covered in this report include carbon and low alloy steels, $\mathrm{Cu}-\mathrm{Ni}$ and $\mathrm{Ni}-\mathrm{Cu}$ alloys, stainless steels, Ni-rich and Ni-base alloys, and $\mathrm{Ti}$ and its alloys. A discussion on galvanic corrosion susceptibility of welded joints containing dissimilar metals is also included. 
Results of several studies on the effect of coupling carbon steel to many different metals and alloys in a range of environments have been presented in this report. These environments include industrial, urban/rural, marine, natural water, and seawater. Even though the precise environment surrounding the waste packages in the potential repository is yet to be determined, the various tested environments cited in this report should cover possible environmental conditions that might be encountered by the candidate container materials. An evaluation of the corrosion data from the reference studies indicate that $\mathrm{Fe}$ $\mathrm{Ni}$-Cr-Mo Alloy 825 and Ni-base Alloy 600 may be cathodically protected due to coupling to carbon or mild steel while exposed to industrial and urban/rural atmospheres, and natural water for periods over one year. However, in seawater, both alloys may undergo corrosive damage, showing measurable corrosion rates. No quantitative corrosion data is available on Alloy 625, galvanically coupled to carbon steel in a similar environment. Limited data on galvanic corrosion of Nitronic 50 stainless steel, coupled to Alloy 625 and Ti-621, respectively, indicate zero current in these two couples, with Ti couple showing a slight weight loss. These types of corrosion data can provide assistance in selecting dissimilar materials having galvanic compatibility.

Electrochemical measurements useful in galvanic corrosion include corrosion potentials, galvanic currents, and polarization curves. A list of corrosion potentials in a specified environment forms the galvanic series for that environment. Any alloy is subject to galvanic corrosion when coupled to another cathodic alloy with a more noble corrosion potential in the galvanic series. The cathodic alloy will be beneficially protected from corrosion at the same time. Rates of galvanic corrosion cannot be derived from the galvanic series but can be measured electrochemically from galvanic currents in a galvanic couple. Galvanic corrosion rates (currents) can be predicted from the intersection of the combined cathodic and anodic polarization curves in diagrams of an array of such curves for all relevant alloys in any specified environment. The polarization curves can be used in modeling studies to predict the efficacy of cathodic protection of the inner corrosionresistant cathodic alloys and crevice corrosion effects in the waste package containers as the outer anodic corrosion-allowance alloy is consumed in service.

Apart from environmental parameters, factors unique to galvanic corrosion include anodeto-cathode area ratio, electrolyte resistivity, and geometric shapes. An unfavorable area ratio exists when the surface area of the more noble metal is larger compared to that of the active metal. Electrolyte resistance may be varied by changing the distance between the two electrodes. In order to prevent or minimize galvanic corrosion, several measures can be taken. Combinations of metals or alloys widely separated in the relevant galvanic series should be avoided. Unfavorable area ratios should also be avoided. Metal combinations should be used in which the more anodic metal or alloy surface is relatively larger. Other factors, such as the presence of crevices, will have a detrimental effect on the behavior of the galvanic couple, and should, therefore, be minimized. 


\section{Acknowledgments}

This work was supported by the U.S. Department of Energy, Office of Civilian Radioactive Waste Management, Yucca Mountain Site Characterization Office, Las Vegas, NV, and performed under the auspices of the U.S. Department of Energy by the Lawrence Livermore National Laboratory under contract number W-7405-ENG-48 and by TRW Environmental Safety Systems Inc. under contract number DE-AC01-RW00134.

Acknowledgment is also made to Dr. E. N. Dalder for collecting a majority of the reference materials used in this report.

\section{References}

1. D. R. McIntyre and C. P. Dillon, Materials Technology Institute, Publication No. 15, St. Louis, p. 15, 1985.

2. C. P. Dillon, Materials Performance, Vol. 29, No. 12, p. 66, 1990.

3. J. C. Farmer et al., "Survey of Degradation Modes of Candidate Materials for High-Level Radioactive-Waste Disposal Containers," LLNL UCID-21362, Vols. 3-5, 1988.

4. C. Wagner and W. Traud, Zeitschririft fur Electrochemie, Vol. 44, p.391, 1938.

5. H. P. Hack, "Evaluation of Galvanic Corrosion," ASM Handbook, Vol. 13, Corrosion, 9th ed., ASM, Metals Park, OH, p. 234, 1987.

6. D. A. Jones, Principles and Prevention of Corrosion, 2nd ed., Prentice-Hall, Saddle River, NJ, p. 174, 1996.

7. R. H. Brown and R. B. Mears, Transactions, Electrochemical Society, Vol. 74, p. $510,1938$.

8. D. A. Jones, Electrochem. Technol., Vol. 6, p. 241, 1968.

9. D. C. Bennett, M.S. Thesis, University of Connecticut, 1972.

10. D. A. Jones, Principles and Prevention of Corrosion, 2nd ed., Prentice-Hall, Saddle River, NJ, p. 185, 1996.

11. H. P. Hack and J. C. Scully, Corrosion, Vol. 42, p. 79, 1986.

12. H. R. Copson, Trans. Electrochem. Soc., Vol. 84, p. 71, 1943. 
13. H. Kaesche, Metallic Corrosion, R. A. Rapp, transl., NACE, Houston, p. 301, 1985.

14. J. T. Waber, et al., J. Electrochem. Soc., Vol. 101, p. 271, 1954; Vol. 102, p. 344, 1955; Vol. 102, p. 420, 1955; Vol. 103, p. 64, 1956, Vol. 103, p. 138, 1956; Vol. 103, p. 567, 1956.

15. J. W. Fu, Corrosion, Vol. 38, p. 296, 1982.

16. A. Aoki et al., Corrosion, Vol. 44, p. 926, 1988.

17. K. E. Johnson and J. S. Abbott, "Bimetallic Corrosion Effects on Mild Steel in Natural Environments," British Steel Corporation, Report No. CEL/CC/5/75, February 1975.

18. R. J. Schmitt and E. H. Phelps, "Constructional Steels in Marine Applications," Journal of Metals, pp. 47-55, March 1970.

19. K. Elayaperumal et al., "Galvanic Corrosion of Carbon Steel - Case Study, Mechanism and Inhibition," Corrosion \& Maintenance, p. 33, Jan-March 1979.

20. B. Tsujino and S. Miyase, "The Galvanic Corrosion of Steel in Sodium Chloride Solution," Corrosion, Vol. 38, No. 4, p. 226, April 1982.

21. W. W. Kirk et al., "Corrosion Behavior of High-Strength Steels in Marine Environments," Metals Engineering Quarterly, American Society for Metals, p. 31, November 1968.

22. S. H. Sanad and A. A. Khedr, "Corrosion and Galvanic Corrosion of Steels in Distilled, Tap and Sea Water," Egypt. J. Chem. Vol. 37, No. 5, 1994.

23. C. R. Southwell et al., "Corrosion of Metals in Tropical Environments - Final Report of 16-Year Exposures," Materials Performance, p. 9, July 1976.

24. V. Kucera and E. Mattsson, "Atmospheric Corrosion of Bimetallic Structures," Atmospheric Corrosion, Hollywood Florida, 5-10 October 1980, John Wiley \& Sons, Inc., pp. 561-574, 1982.

25. Y. Yamaguchi et al., The Thermal and Nuclear Power, Vol. 25, p. 172, 1974.

26. A. Kawabe et al., The Thermal and Nuclear Power, Vol. 27, p. 569, 1976

27. Y. Hisatomi et al., The Thermal and Nuclear Power, Vol. 29, p. 771, 1978 
28. H. Kunieda et al., "Galvanic Corrosion of Some Copper Alloys Coupled with Titanium in Synthetic Sea Water," Furukawa Metals Co., Ltd., Amagasaki-shi, Japan.

29. G. A. Storm, "The Effects of Velocity on Corrosion of Galvanic Couples in Seawater," M.Sc Thesis, Naval Postgraduate School, September 1977.

30. B. Wallen and T. Andersson, "Galvanic Corrosion of Copper Alloys in Contact with a Highly Alloyed Stainless Steel in Seawater," Paper No. 29, pp. 149-154 10th Scandinavian Corrosion Congress, Stockholm, 1986.

31. C. R. Southwell and A. L. Alexander, in Corrosion of Metals in Tropical Environments, Part 8 - Nickel and Nickel-Copper Alloys - Sixteen Years' Exposure, NRL Report 6592, Naval Research Laboratory, Washington, D. C., October 4, 1967.

32. R. Baboian et al., "Atmospheric Corrosion of Laminar Composites Consisting of Copper on Stainless Steel," Atmospheric Factors Affecting the Corrosion of Engineering Metals, ASTM STP 646, S. K. Coburn, Ed., American Society for Testing and Materials, pp. 185-203, 1978.

33. M. Pourbaix, Corrosion, Vol. 26, p. 431, 1970.

34. J. M. Defranoux, Corrosion Science, Vol. 3, p. 75, 1963.

35. E. Escalante and W. F. Gerhold, "The Galvanic Coupling of Some Stainless Steels to Copper - Underground," Materials Performance, p. 16, October 1975.

36. I. L. Caplan, "Mechanical Properties and Seawater Behavior of Nitronic 50 (22Cr-13Ni-5Mn) Plate," Report No. 4554, David W. Taylor Naval Ship Research and Development Center, Bethesda, MD 20084, January 1976.

37. Y. J. Gau and J. K. Wu, "Galvanic Corrosion Behavior of Fe-Mn-Al Alloys in Seawater," JOM Science Letters, Vol. 11, Issue 2, pp. 119-121, January 1992.

38. E. Escalante and W. F. Gerhold, "Galvanic Coupling of Some Stressed Stainless Steels to Dissimilar Metals Underground," Galvanic and Pitting Corrosion - Field and Laboratory Studies, ASTM STP 576, American Society for Testing and Materials, pp. 81-93, 1976.

39. R. D. Kane et al., "Factors Influencing the Embrittlement of Cold Worked High Alloy Materials in $\mathrm{H}_{2}$ S Environments," Corrosion, Vol. 33, No. 9, September 1977. 
40. S. S. Chouthai and H. S. Gadiyar, "Corrosion of Titanium \& Zirconium in Methanol-HCl Medium in Contact with Stainless Steel, Monel \& Inconel," J. Electrochem. Soc. India, Vol. 33-1, p. 15, 1984.

41. R. N. Duncan and T. L. Amey, "Galvanic Corrosion Behavior of Electroless Nickel in Seawater," Plating and Surface Finishing, p.60, October 1989.

42. Z. A. Foroulis, "Galvanic Behavior of Titanium in Contact with Carbon Steel and Several Alloys in Aqueous Sulfidic Solutions," Materials Performance, p. 29, September 1980.

43. L. A. Shalaby, "Galvanic Coupling of Ti with $\mathrm{Cu}$ and $\mathrm{Al}$ Alloys in Chloride Media," Corrosion Science, Vol. 11, pp. 767-778, Pergamon Press, U. K., 1971.

44. L. Lunde, "Properties of Titanium Alloys - Corrosion and Galvanic Compatibility," Doc. No. IFE/KR/E-91/001, Institutt for energiteknikk, Norway, January 1991.

45. K. Kohsaka et al., "Light Gauge Welded Titanium Tubes for Seawater Desalination Plants," Desalination, Vol. 73, pp. 429-446, 1989.

46. J. Gluszek and J. Masalski, "Galvanic Coupling of 316L Steel with Titanium, Niobium, and Tantalum in Ringer's Solution," Brit. Corr. J, Vol. 27, No. 2, p. 135, 1992.

47. X. Zhu et al., "Study on Galvanic Corrosion of Titanium Alloys in Seawater," Sixth World Conference on Titanium, France, p. 1901, 1988.

48. L. C. Covington and R. W. Schutz, "Effects of Iron on the Corrosion Resistance of Titanium," Industrial Applications of Titanium and Zirconium, ASTM STP 728, E. W. Kleefisch, Ed., American Society for Testing and Materials, pp. 163-180, 1981.

49. N. D. Tomashov and R. M. Al'Tovskii, Corrosion, Vol. 19, pp. 217-221, June 1963.

50. R. W. Schutz and D. E. Thomas, "Corrosion of Titanium and Titanium Alloys," ASM Handbook, Vol. 13, Corrosion, 9th ed., ASM, Metals Park, OH, p. 669, 1987.

51. J. C. Griess, Corrosion, Vol. 24, p. 96, 1968.

52. A. V. A. Saarinen, "The Effect of Microstructure on the HAZ Corrosion of Shipbuilding Steel," Proceedings ICSTIS, Suppl. ISIJ, Vol. 11, p. 1101, 1971. 
53. K. Relander and K. Onnela, "Corrosion Behavior of Heat-Affected Zones in Welded Ships," Jernkont. Ann. Vol. 154, p. 173, 1970.

54. A. Saarinen and K. Onnela, "A Method for Testing the Corrodibility of HeatAffected Zones in Steel," Corrosion Science, Vol. 10, p. 809, Pergamon Press, U. K., 1970.

55. A. McMinn and R. A. Page, "Stress Corrosion Cracking of Inconel Weldments in a Simulated BWR Environment," Corrosion, Vol. 44, No. 4, pp. 239-247, April 1988.

56. N. Lindsey and K. L. Vasanth, "Corrosion Characterization of Explosively Bonded Materials in Marine Environment," 12th International Corrosion Congress; Proceeding, Houston, pp. 3645-3659, 19-24 September, 1993. 
Tables 
Table 1

Nominal Compositions of Candidate Container Materials

\begin{tabular}{|c|c|c|c|c|c|c|c|c|c|c|c|c|c|c|}
\hline Material & ASTM No. & $\underline{\mathrm{C}}$ & $\underline{\mathrm{Mn}}$ & $\underline{\mathbf{p}}$ & $\underline{\mathbf{S}}$ & $\underline{\mathbf{S i}}$ & $\underline{\mathrm{Ni}}$ & $\underline{\mathrm{Cr}}$ & $\underline{\text { Mo }}$ & $\underline{\mathrm{Fe}}$ & $\underline{\mathrm{T}}$ & $\underline{\mathrm{Al}}$ & $\underline{\mathrm{Cu}}$ & Others \\
\hline $1020 \mathrm{CS}$ & A 516 & $\begin{array}{l}0.22 \\
(\max )\end{array}$ & $\begin{array}{r}0.60 \\
-1.2\end{array}$ & $\begin{array}{l}0.035 \\
(\max )\end{array}$ & $\begin{array}{l}0.035 \\
(\max )\end{array}$ & $\begin{array}{l}0.15 \\
-0.40\end{array}$ & - & - & - & Bal & - & - & - & - \\
\hline $2.25 \mathrm{Cr}-1 \mathrm{Mo}$ & A 387 & $\begin{array}{l}0.15 \\
(\max )\end{array}$ & $\begin{array}{l}0.30 \\
-0.60\end{array}$ & $\begin{array}{l}0.035 \\
(\max )\end{array}$ & $\begin{array}{l}0.035 \\
(\max )\end{array}$ & $\begin{array}{l}0.50 \\
(\max )\end{array}$ & - & $\begin{array}{l}2.00 \\
-2.50\end{array}$ & $\begin{array}{l}0.90 \\
-1.10\end{array}$ & Bal & - & - & - & - \\
\hline $70 / 30 \mathrm{Cu}-\mathrm{Ni}$ & B 171 & $\begin{array}{l}0.05 \\
(\max )\end{array}$ & $\begin{array}{l}1.00 \\
(\max )\end{array}$ & $\begin{array}{l}0.02 \\
(\max )\end{array}$ & $\begin{array}{l}0.02 \\
(\max )\end{array}$ & - & $\begin{array}{l}29.00 \\
-33.0\end{array}$ & - & - & $\begin{array}{r}0.40 \\
-1.0\end{array}$ & - & - & Bal & $\operatorname{Zn} 0.5(\max )$ \\
\hline Alloy 400 & B 127 & $\begin{array}{l}0.03 \\
(\max )\end{array}$ & $\begin{array}{l}2.00 \\
(\max )\end{array}$ & - & $\begin{array}{l}0.024 \\
(\max )\end{array}$ & $\begin{array}{l}0.50 \\
(\max )\end{array}$ & $\begin{array}{l}63.00 \\
(\mathrm{~min})\end{array}$ & - & - & $\begin{array}{l}2.50 \\
(\max )\end{array}$ & - & - & $\begin{array}{r}28.00 \\
-34.0\end{array}$ & - \\
\hline Alloy 825 & B 424 & $\begin{array}{l}0.05 \\
(\max )\end{array}$ & $\begin{array}{l}1.00 \\
(\max )\end{array}$ & - & $\begin{array}{l}0.03 \\
(\max )\end{array}$ & $\begin{array}{l}0.50 \\
(\max )\end{array}$ & $\begin{array}{l}38.00 \\
-46.0\end{array}$ & $\begin{array}{r}19.50 \\
-23.5\end{array}$ & $\begin{array}{r}2.50 \\
-3.5\end{array}$ & Bal & $\begin{array}{r}0.60 \\
-1.2\end{array}$ & $\begin{array}{l}0.20 \\
(\max )\end{array}$ & $\begin{array}{r}1.50 \\
-3.0\end{array}$ & - \\
\hline Alloy G-3 & B 582 & $\begin{array}{l}0.015 \\
(\max )\end{array}$ & $\begin{array}{l}1.00 \\
(\max )\end{array}$ & $\begin{array}{l}0.04 \\
(\max )\end{array}$ & $\begin{array}{l}0.03 \\
\text { (max) }\end{array}$ & $\begin{array}{l}1.00 \\
(\max )\end{array}$ & Bal & $\begin{array}{l}21.00 \\
-23.5\end{array}$ & $\begin{array}{r}6.00 \\
-8.0\end{array}$ & $\begin{array}{l}18.00 \\
-21.0\end{array}$ & - & - & $\begin{array}{r}1.50 \\
-2.5\end{array}$ & Co 5.0 (max) \\
\hline Alloy G-30 & B 582 & $\begin{array}{l}0.03 \\
(\max )\end{array}$ & $\begin{array}{l}1.50 \\
(\max )\end{array}$ & $\begin{array}{l}0.04 \\
(\max )\end{array}$ & $\begin{array}{l}0.02 \\
(\max )\end{array}$ & $\begin{array}{l}0.80 \\
\text { (max) }\end{array}$ & Bal & $\begin{array}{l}28.0 \\
-31.5\end{array}$ & $\begin{array}{l}4.00 \\
-6.0\end{array}$ & $\begin{array}{r}13.00 \\
-17.0\end{array}$ & - & - & $\begin{array}{r}1.00 \\
-2.4\end{array}$ & Co $5.0(\max )$ \\
\hline Alloy 625 & B 443 & $\begin{array}{l}0.10 \\
(\max )\end{array}$ & $\begin{array}{l}0.50 \\
(\max )\end{array}$ & $\begin{array}{l}0.015 \\
(\max )\end{array}$ & $\begin{array}{l}0.015 \\
(\max )\end{array}$ & $\begin{array}{l}0.50 \\
\text { (max) }\end{array}$ & $\begin{array}{l}58.0 \\
(\mathrm{~min})\end{array}$ & $\begin{array}{l}20.0 \\
-23.0\end{array}$ & $\begin{array}{l}8.00 \\
-10.0\end{array}$ & $\begin{array}{l}5.00 \\
(\max )\end{array}$ & $\begin{array}{l}0.40 \\
(\max )\end{array}$ & $\begin{array}{l}0.40 \\
(\max )\end{array}$ & - & $\begin{array}{l}\mathrm{Cb}+\mathrm{Ta}(3.15 \\
\mathrm{Co} 1.0-4.15) \\
(\max )\end{array}$ \\
\hline Alloy C-4 & B 575 & $\begin{array}{l}0.015 \\
(\max )\end{array}$ & $\begin{array}{l}1.00 \\
(\max )\end{array}$ & $\begin{array}{l}0.04 \\
(\max )\end{array}$ & $\begin{array}{l}0.03 \\
(\max )\end{array}$ & $\begin{array}{l}0.80 \\
(\max )\end{array}$ & Bal & $\begin{array}{r}14.00 \\
-18.0\end{array}$ & $\begin{array}{r}14.00 \\
-17.0\end{array}$ & $\begin{array}{l}3.00 \\
(\max )\end{array}$ & $\begin{array}{l}0.70 \\
(\max )\end{array}$ & - & - & Co 2.0 (max) \\
\hline Alloy C-22 & B 575 & $\begin{array}{l}0.015 \\
(\max )\end{array}$ & $\begin{array}{l}0.50 \\
(\max )\end{array}$ & $\begin{array}{l}0.02 \\
(\max )\end{array}$ & $\begin{array}{l}0.02 \\
(\max )\end{array}$ & $\begin{array}{l}0.80 \\
(\max )\end{array}$ & Bal & $\begin{array}{r}20.00 \\
-22.0\end{array}$ & $\begin{array}{l}12.50 \\
-14.50\end{array}$ & $\begin{array}{l}2.00 \\
-6.0\end{array}$ & - & - & . & $\begin{array}{l}\text { W } 2.5-3.5 \\
\text { Co } 2.5 \text { (max) } \\
\text { V } 0.35 \text { (max) }\end{array}$ \\
\hline Ti Grade-12 & B 265 & $\begin{array}{l}0.08 \\
(\max )\end{array}$ & - & - & - & - & $\begin{array}{l}0.60 \\
-0.90\end{array}$ & - & $\begin{array}{r}0.20 \\
-0.4\end{array}$ & $\begin{array}{l}0.30 \\
(\max )\end{array}$ & $\mathrm{Bal}$ & - & - & $\begin{array}{l}\text { N } 0.03 \text { (max) } \\
\text { H } 0.015 \text { (max) } \\
\text { O } 0.25 \text { (max) }\end{array}$ \\
\hline
\end{tabular}




\section{Table 2}

\section{Corrosion Rates of Mild Steel Coupled to Other Metals in Industrial Atmosphere ${ }^{(17)}$}

\begin{tabular}{|c|c|c|}
\hline \multirow{2}{*}{ Comple } & \multicolumn{2}{|c|}{ Cormsion Rates, $\mathrm{g} / \mathrm{m}^{\text {? }}$ day } \\
\hline & Mild Steel & Other Metal \\
\hline Mild Steel - Aluminium S1A & 1.29 & 0.20 \\
\hline Mild Steel - Aluminium NS3 & 1.17 & 0.22 \\
\hline Mild Steel - Aluminium NS4 & 1.08 & 0.44 \\
\hline Mild Steel - Ahuminium Bronze & 1.81 & 0.05 \\
\hline Mild Steel - Brass & 1.74 & 0.12 \\
\hline Mild Steel - Cadmium & 0.15 & Cd Flaked \\
\hline Mild Steel - Cartion & 1.95 & 0.00 \\
\hline Mild Steel - Cast Iron & 1.46 & 1.75 \\
\hline Mild Steel - Chromium & 1.40 & 0.00 \\
\hline Mild Steel - Copper & 1.77 & 0.09 \\
\hline Mild Steel - Cor-Ten & 1.50 & 0.84 \\
\hline Mild Steel - Cupronickel $90 \mathrm{Cu}-1 \mathrm{aNi}$ & 2.05 & 0.06 \\
\hline Mild Steel - Gun Metal & 1.91 & 0.05 \\
\hline Mild Steel - Hastelloy B & 1.52 & 0.10 \\
\hline Mild Steel - Inco Joy $\mathbf{8 0 0}$ & 1.78 & 0.00 \\
\hline Mild Steel - Incoloy 825 & 1.83 & 0.00 \\
\hline Mild Steel - Incomel 600 & 2.13 & 0.00 \\
\hline Mild Steel - Lead & 1.23 & 0.15 \\
\hline Mild Steel - Magnesium & 0.01 & 1.12 \\
\hline Mild Steel - Magnesium AZ31B & 0.01 & 0.88 \\
\hline MILD STEEL - MILD STEEL & 1.45 & \\
\hline Mild Steel - Monel $\mathbf{4 0 0}$ & 2.11 & 0.03 \\
\hline Mild Steel - Nicksel 200 & S.D. & S.D. \\
\hline Mild Steel - Niclsel Silver & 2.14 & 0.05 \\
\hline Mild Steel - Silver Solder. & 1.80 & 0.08 \\
\hline Mild Steel - Soft Solder & 1.19 & 0.14 \\
\hline Mild Steel - Stainless Steel Type 410 & 1.66 & 0.03 \\
\hline Mild Steel - Stainless Steel Type 304 & S. D. & S.D. \\
\hline Mild Steel - Stainless Steel Type 316 & 1.99 & 0.02 \\
\hline Mild Steel - Stainless Steel Type 430 & S. D. & S.D. \\
\hline Mild Steel - Tin & 1.53 & 0.12 \\
\hline Mild Steel - Zinc & 0.59 & 0.90 \\
\hline
\end{tabular}

S.D. - Specimen damaged 
Table 3

\section{Corrosion Rates of Mild Steel Coupled to Other Metals in Urban/Rural Atmosphere ${ }^{(17)}$}

\begin{tabular}{|c|c|c|}
\hline \multirow{2}{*}{ Couple } & \multicolumn{2}{|c|}{ Corrosion Rates, $\mathrm{g} / \mathrm{m}^{2}$ day } \\
\hline & Mild Steel & Other Metal \\
\hline Mild Steel - Aluminium S1A & 0.68 & 0.15 \\
\hline Mild Steel - Aluminium NS3 & 0.78 & 0.15 \\
\hline Mild Steel - Aluminium NS4 & 0.73 & 0.32 \\
\hline Mild Steel - Aluminium Bronze & 1.32 & 0.01 \\
\hline Mild Steel - Brass & 1.43 & 0.09 \\
\hline Mild Steel - Cadmium & 0.10 & 0.60 \\
\hline Mild Steel - Carbon & 1.52 & 0.00 \\
\hline Mild Steel - Cast Iron & 0.88 & 1.15 \\
\hline Mild Steel - Chromium & 1.20 & 0.00 \\
\hline Mild Steel - Copper & 1.15 & 0.01 \\
\hline Mild Steel - Cor-Ten & 0.82 & 0.83 \\
\hline Mild Steel - Cupronickel 90Cu-10Ni & 1.26 & 0.01 \\
\hline Mild Steel - Gun Metal & 1.42 & 0.05 \\
\hline Mild Steel - Hastelloy B & 1.07 & 0.14 \\
\hline Mild Steel - Incoloy 800 & S. D. & S.D. \\
\hline Mild Steel - Incoloy 825 & 1.08 & 0.00 \\
\hline Mild Steel - Inconel 600 & 1.04 & 0.00 \\
\hline Mild Steel - Lead & 0.91 & 0.28 \\
\hline Mild Steel - Magnesium & 0.02 & 1.17 \\
\hline Mild Steel - Magnesium AZ31B & 0.01 & 0.85 \\
\hline MID STEEL - MILD STEEL & 0.89 & \\
\hline Mild Steel - Monel 400 & 1.16 & 0.01 \\
\hline Mild Steel - Nickel 200 & 0.99 & 0.04 \\
\hline Mild Steel - Nickel Silver & 1.12 & 0.05 \\
\hline Mild Steel - Silver Solder & 1.32 & 0.03 \\
\hline Mild Steel - Soft Solder & 0.74 & 0.14 \\
\hline Mild Stee1 - Stainless Steel Type 410 & 1.28 & 0.00 \\
\hline Mild Steel - Stainless Steel Type 304 & 1.11 & 0.01 \\
\hline Mild Steel - Stainless Steel Type 316 & 1.12 & 0.01 \\
\hline Mild Steel - Stainless Steel T ype 430 & 1.16 & 0.02 \\
\hline Mild Steel - Tin & 0.90 & 0.08 \\
\hline Mild Steel - Zinc & 0.10 & 0.88 \\
\hline
\end{tabular}

S.D. - Specimen damaged 
Table 4

\section{Corrosion Rates of Mild Steel Coupled to Other Metals in Marine Atmosphere ${ }^{(17)}$}

\begin{tabular}{|c|c|c|c|}
\hline \multirow{3}{*}{ Couple } & \multicolumn{3}{|c|}{ Corrosion Rates, $\mathrm{g} / \mathrm{m}^{2}$ day } \\
\hline & \multirow[t]{2}{*}{ Mild Steel } & \multicolumn{2}{|c|}{ Other Metal } \\
\hline & & $\begin{array}{l}\text { Coupled } \\
\text { to Mild } \\
\text { Steel }\end{array}$ & $\begin{array}{l}\text { Coupled } \\
\text { to } \\
\text { Itself }\end{array}$ \\
\hline Mild Steel - Aluminium SIA & 0.20 & 1.35 & 0.04 \\
\hline Mild Steel - Aluminium NS3 & 0.24 & 1.51 & 0.03 \\
\hline Mild Steel - Aluminium NSt & 0.24 & 1.55 & 0.03 \\
\hline Mild Steel - Aluminium: & 2.68 & 0.06 & 0.06 \\
\hline Mild Steel - Brass & S.D. & S.D. & 0.07 \\
\hline Mild Steel - Cadmium & 0.09 & Cd flaked & 0.10 \\
\hline Mild Steel - Carbon & S.D. & $\begin{array}{l}\text { Weight } \\
\text { gain }\end{array}$ & 0.01 \\
\hline Mild Steel - Cast Iron & 1.60 & 1.07 & 1.26 \\
\hline Mild Steel - Chromium & 2.03 & Cr flaked & Cr flaked \\
\hline Mild Steel - Copper & S.D. & S.D. & 0.04 \\
\hline Mild Steel - Cor-Ten & 2.14 & 1.21 & 1.46 \\
\hline Mild Steel - Cupronickel $90 \mathrm{Cu}-10 \mathrm{Ni}$ & 3.34 & 0.09 & 0.05 \\
\hline Mild Steel - Gun Metal & S.D. & S.D. & 0.08 \\
\hline Mild Steel - Hastelloy B & 2.35 & 0.11 & 0.08 \\
\hline Mild Steel - Incoloy $\mathbf{8 0 0}$ & 3.85 & 0.00 & - \\
\hline Mild Steel - Incoloy 825 & S.D. & S.D. & - \\
\hline Mild Steel - Inconel 600 & 2.91 & 0.00 & - \\
\hline Mild Steel - Lead & 0.92 & 0.35 & 0.15 \\
\hline Mild Steel - Magnesium & N.D. & $\begin{array}{l}\text { Specimen } \\
\text { destroyed }\end{array}$ & $\begin{array}{l}\text { Specimen } \\
\text { destroyed }\end{array}$ \\
\hline Mild Steel - Magnesium AZ31 B & 0.01 & 1.31 & 0.27 \\
\hline MILD STEEL - MILD STEEL & 1.05 & & \\
\hline Mild Steel - Monel 400 & S.D. & S.D. & - \\
\hline Mild Steel - Nickel 200 & 2.12 & 0.07 & - \\
\hline Mild Steel - Nickel Silver & 1.87 & 0.05 & - \\
\hline Mild Steel - Silver Solder & S.D. & S.D. & 0.05 \\
\hline Mild Steel - Soft Solder & 0.87 & 0.30 & 0.19 \\
\hline Mild Steel - Stainless Steel Type 410 & 1.95 & 0.03 & 0.08 \\
\hline Mild Steel - Stainless Steel Type 304 & 2.35 & 0.01 & 0.02 \\
\hline Mild Steel - Stainless Steel Type 316 & S.D. & S.D. & 0.01 \\
\hline Mild Steel - Stainless Steel Type $\mathbf{4 3 0}$ & 1.80 & 0.02 & 0.03 \\
\hline Mild Steel - Tin & 1.46 & 0.24 & 0.18 \\
\hline Mild Steel - Zinc & 0.11 & 1.35 & 0.12 \\
\hline
\end{tabular}

S.D. - Specimen damaged

N.D. - Not determined 
Table 5

\section{Corrosion Rates of Mild Steel Coupled to Other Metals in Natural Water ${ }^{(1)}$}

\begin{tabular}{|c|c|c|}
\hline \multirow{2}{*}{ Couple } & \multicolumn{2}{|c|}{ Corrosion Rates, $\mathrm{g} / \mathrm{m}^{2}$ day } \\
\hline & Mild Steel & Other Metal \\
\hline Mild Steel - Aluminium S1A & 2.40 & 0.29 \\
\hline Mild Steel - Aluminium NS3 & 2.59 & 0.13 \\
\hline Mild Steel - Aluminium NS4 & $\mathbf{S . D}$ & S.D. \\
\hline Mild Steel - Aluminium Bronze & 4.00 & 0.00 \\
\hline Mild Steel - Brass & 4.07 & 0.00 \\
\hline Mild Steel - Cadmium & 1.36 & 2.75 \\
\hline Mild Steel - Carbon & S.D. & S.D. \\
\hline Mild Steel - Cast Iron & 1.84 & 2.93 \\
\hline Mild Steel - Chromium & 2.20 & 0.04 \\
\hline Mild Steel - Copper & 3.80 & 0.00 \\
\hline Mild Steel - Cor-Ten & 2.64 & 1.70 \\
\hline Mild Steel - Cupronickel 90Cu-1 aNi & 3.97 & 0.00 \\
\hline Mild Steel - Gun Metal & 3.59 & 0.00 \\
\hline Mild Steel - Hastelloy B & 2.39 & 0.40 \\
\hline MLild Steel - Incoloy $\mathbf{8 0 0}$ & 2.88 & 0.00 \\
\hline Mild Steel - Incoloy 825 & 3.25 & 0.00 \\
\hline Mild Steel - Inconel 600 & 3.49 & 0.02 \\
\hline Mild Steel - Lead & 1.65 & 1.34 \\
\hline Mild Steel - Magnesium & N.D. & $\begin{array}{l}\text { Specimen } \\
\text { destroyed }\end{array}$ \\
\hline Mild Steel - Magnesium AZ31 B & N.D. & $\begin{array}{l}\text { Specimen } \\
\text { destroyed }\end{array}$ \\
\hline MILD STEEL - MILD STEEL & 1.89 & \\
\hline Mild Steel - Monel 400 & 3.71 & 0.04 \\
\hline Mild Steel - Nickel 200 & 2.88 & 0.04 \\
\hline Mild Steel - Nickel Silver & 3.89 & $\begin{array}{l}\text { Specimen } \\
\text { lost }\end{array}$ \\
\hline Mild Steel - Silver Solder & 3.40 & 0.00 \\
\hline Mild Steel - Soft Solder & 5.86 & 0.36 \\
\hline Mild Steel - Stainless Steel Type 410 & 3.06 & 0.01 \\
\hline Mild Steel - Stainless Steel Type 304 & 3.13 & 0.01 \\
\hline Mild Steel - Stainless Steel Type 316 & 4.11 & 0.02 \\
\hline Mild Steel - Stainless Steel Type 430 & 3.37 & 0.02 \\
\hline Mild Steel - Tin & 2.55 & 0.05 \\
\hline Mild Steel - Zinc & 0.04 & 3.64 \\
\hline
\end{tabular}

S.D. - Specimen damaged

N.D. - Not determined 
Table 6

\section{Corrosion Rates of Mild Steel Coupled to Other Metals in Seawater ${ }^{(17)}$}

\begin{tabular}{|c|c|c|c|}
\hline \multirow{3}{*}{ Couple } & \multicolumn{3}{|c|}{ Corrosion Rates, $g / m^{2}$ day } \\
\hline & \multirow[t]{2}{*}{ Mild Steel } & \multicolumn{2}{|c|}{ Other Metal } \\
\hline & & $\begin{array}{l}\text { Coupled } \\
\text { to Mild } \\
\text { Steel }\end{array}$ & $\begin{array}{l}\text { Coupled } \\
\text { to } \\
\text { Itself }\end{array}$ \\
\hline Mild Steel - Aluminium S1A & 0.76 & 3.93 & 0.22 \\
\hline Mild Steel - Aluminium NS3 & 0.64 & 6.15 & 0.20 \\
\hline Mild Steel - Aluminium NS4 & 1.07 & 5.54 & 0.42 \\
\hline Mild Steel - Aluminium Bronze & 7.32 & 0.30 & 1.12 \\
\hline Mild Steel - Brass & 9.63 & 0.19 & 4.15 \\
\hline Mild Steel - Cadmium & 4.00 & 7.30 & 4.38 \\
\hline Mild Steel - Carbon & 12.33 & $\begin{array}{l}\text { Weigt.t } \\
\text { gain }\end{array}$ & 0.00 \\
\hline Mild Steel - Cast Iron & 3.12 & 7.51 & 7.02 \\
\hline Mild Steel - Chromium & 6.88 & 0.31 & Cr flaked \\
\hline Mild Steel - Copper & 10.07 & 1.24 & 1.65 \\
\hline Mild Steel - Cor-Ten & 6.23 & 3.21 & 5.06 \\
\hline Mild Steel - Cupronickel $90 \mathrm{Cu}-10 \mathrm{Ni}$ & 11.09 & 0.17 & 1.12 \\
\hline Mild Steel - Gun Metal & 13.27 & 0.22 & 0.28 \\
\hline Mild Steel - Hastelloy B & S.D. & S.D. & 1.09 \\
\hline Mild Steel - Incoloy 800 & 6.08 & 0.07 & - \\
\hline Mild Steel - Incoloy 825 & 10.03 & 0.15 & - \\
\hline Mild Steel - Inconel 600 & 8.66 & 0.16 & - \\
\hline Mild Steel - Lead & 8.54 & 0.43 & 0.87 \\
\hline Mild Steel - Magnesium & N.D. & $\begin{array}{l}\text { Specimen } \\
\text { destroyed }\end{array}$ & $\begin{array}{l}\text { Specimen } \\
\text { destroyed }\end{array}$ \\
\hline Mild Steel - Magnesium AZ31 B & N.D. & $\begin{array}{l}\text { Specimen } \\
\text { destroyed }\end{array}$ & 1.96 \\
\hline MILD STEEL - MILD STEEL & 5.67 & & \\
\hline Mild Steel - Monel $\mathbf{4 0 0}$ & 9.87 & 0.19 & - \\
\hline Mild Steel - Nickel 200 & 8.16 & 0.15 & - \\
\hline Mild Steel - Nickel Silver & 9.65 & 0.08 & - \\
\hline Mild Steel - Silver Solder & 10.38 & 0.18 & 0.12 \\
\hline MIild Steel - Soft Solder & 8.86 & 0.28 & 0.67 \\
\hline Mild Steel - Stainless Stee1 Type 410 & 6.58 & 0.10 & 2.67 \\
\hline Mild Steel - Stainless Steel Type 304 & S.D. & S.D. & 1.85 \\
\hline Mild Steel - Stainless Steel Type 316 & 8.80 & 0.04 & 0.08 \\
\hline Mild Steel - Stainless Steel Type 430 & 8.55 & 0.08 & 2.70 \\
\hline Mild Steel' - Tin & 5.85 & 0.29 & 2.83 \\
\hline Mild Steel - Zinc & 0.17 & 11.40 & 2.24 \\
\hline
\end{tabular}

\footnotetext{
S.D. - Specimen damaged

N.D. - Not determined
} 
Table 7

Effect of Area Ratio on Corrosion Rate of Carbon Steel in Seawater ${ }^{(18)}$

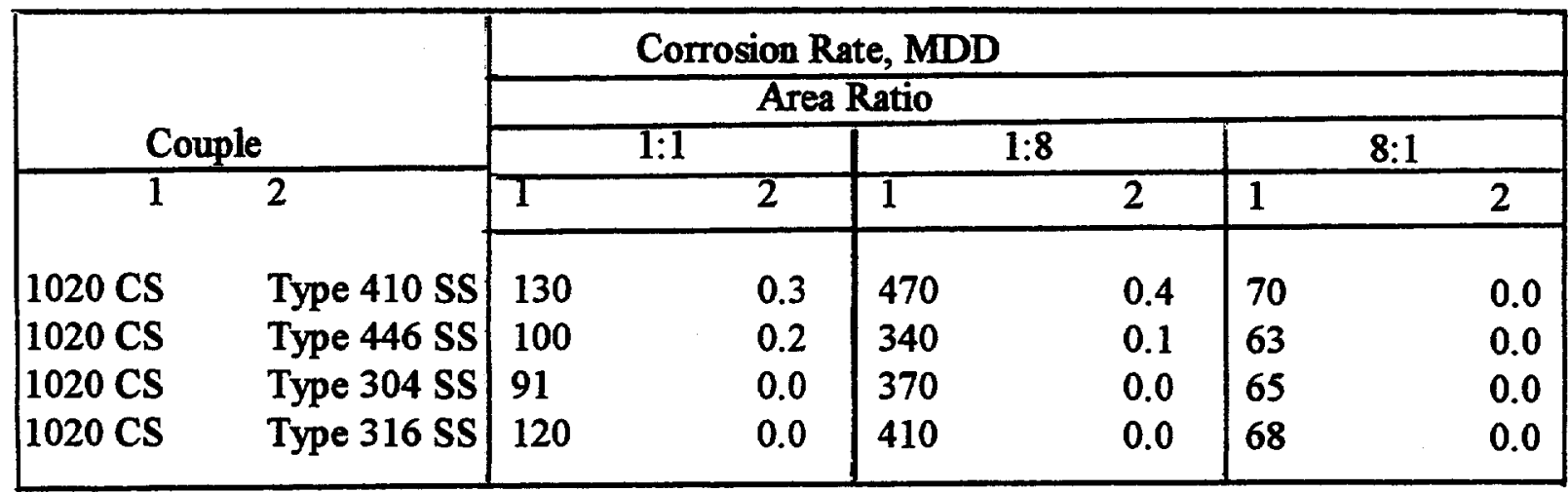

Note: Separation between coupled specimens was about four inches.

\section{Table 8}

Effect of Galvanic Coupling to Different Metals on the Corrosion Rate of Mild Steel in Synthetic Seawater at Room Temperature ${ }^{(19)}$

(Exposure Time : 24 hours)

\begin{tabular}{|l|l|l|}
\hline Coupling Metal & $\begin{array}{l}\text { Corrosion Rate of } \\
\text { Mild Steel, mm/year }\end{array}$ & $\begin{array}{l}\mathrm{I}_{\text {corrosion }} \\
\text { Amps. }\end{array}$ \\
\hline None & 0.56 & $5.50 \times 10^{-4}$ \\
Monel 400 & 1.31 & $1.45 \times 10^{-3}$ \\
Inconel 600 & 0.84 & $7.89 \times 10^{-4}$ \\
Type 304 SS & 0.96 & $1.09 \times 10^{-3}$ \\
Type 316 SS & 0.62 & $6.07 \times 10^{-4}$ \\
Copper & 1.12 & $1.04 \times 10^{-3}$ \\
\hline
\end{tabular}




\section{Table 9}

Results of Polarization Tests of Nitronic 50* Galvanically Coupled with Various Alloys in Flowing Seawater for 30 Days $^{(39)}$

\begin{tabular}{|c|c|c|c|c|c|c|}
\hline \multirow[t]{3}{*}{ Alloy } & \multicolumn{2}{|c|}{ Corrosion Rate, mpy } & \multirow{3}{*}{$\begin{array}{l}\text { Nitronic } 50 \\
\text { Corrosion Rate, } \\
\text { mpy }\end{array}$} & \multirow{2}{*}{\multicolumn{2}{|c|}{$\begin{array}{l}\text { Galvanic } \\
\text { Current, mA }\end{array}$}} & \multirow{3}{*}{$\begin{array}{l}\text { Mixed } \\
\text { Potential } \\
\text { (Range, mV) }\end{array}$} \\
\hline & \multirow[t]{2}{*}{ Coupled } & \multirow{2}{*}{$\begin{array}{l}\text { Freely } \\
\text { Corroding } \\
\end{array}$} & & & & \\
\hline & & & & Avg & Max & \\
\hline HY 80 & 68.6 & 24.3 & Nil & 2.0 & 3.0 & -600 to -640 \\
\hline $90 / 10 \mathrm{Cu}-\mathrm{Ni}$ & 62.3 & 1.80 & Nil & 1.3 & 3.0 & -80 to -170 \\
\hline $70 / 30 \mathrm{Cu}-\mathrm{Ni}$ & 15.2 & 1.90 & Nil & 0.39 & 0.9 & -15 to -170 \\
\hline Monel 400 & 2.7 & 0.10 & Nil & Nil & 0.1 & -30 to -50 \\
\hline Type 304 SS & 15.5 & 2.20 & Nil & 0.25 & 0.6 & -20 to -100 \\
\hline 17-4PH & 38.5 & 16.9 & Nil & 0.67 & 0.9 & -70 to -200 \\
\hline Inconel 625 & Nil & Nil & Nil & Nil & \pm 0.1 & +190 to -90 \\
\hline Ti-621 & 1.8 & Nil & Nil & Nil & \pm 0.1 & +115 to -105 \\
\hline Nitronic 50 & - & 0.60 & 1.7 & - & - & +50 to -70 \\
\hline
\end{tabular}

*Nitronic 50 Stainless Steel ( Fe-13Ni-22Cr-5Mn) is an Armco Steel designation. 
Figures 


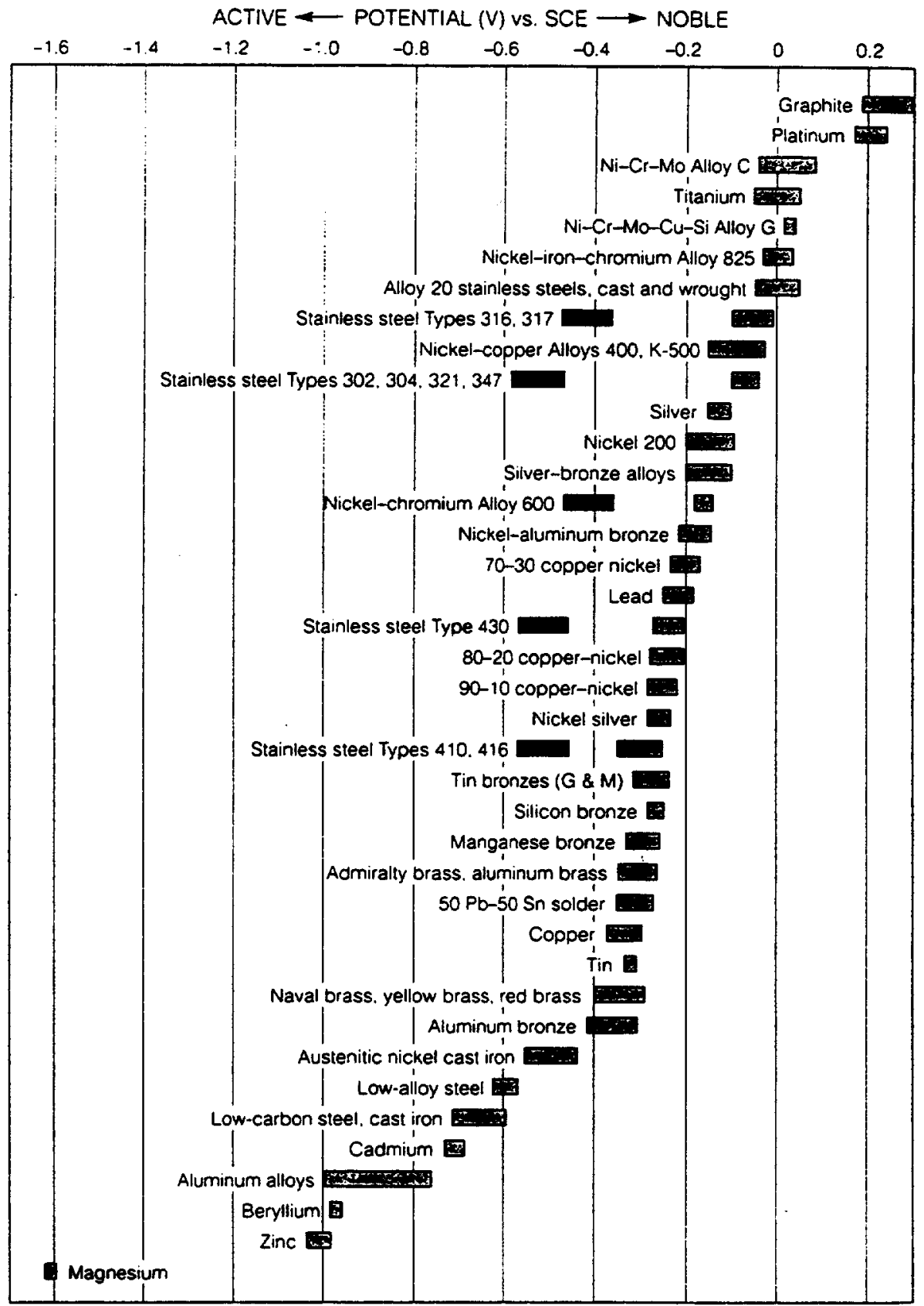

Figure 1. Galvanic Series for Seawater ${ }^{(\text {() }}$. Dark Boxes Indicate Active-Passive Alloys. 


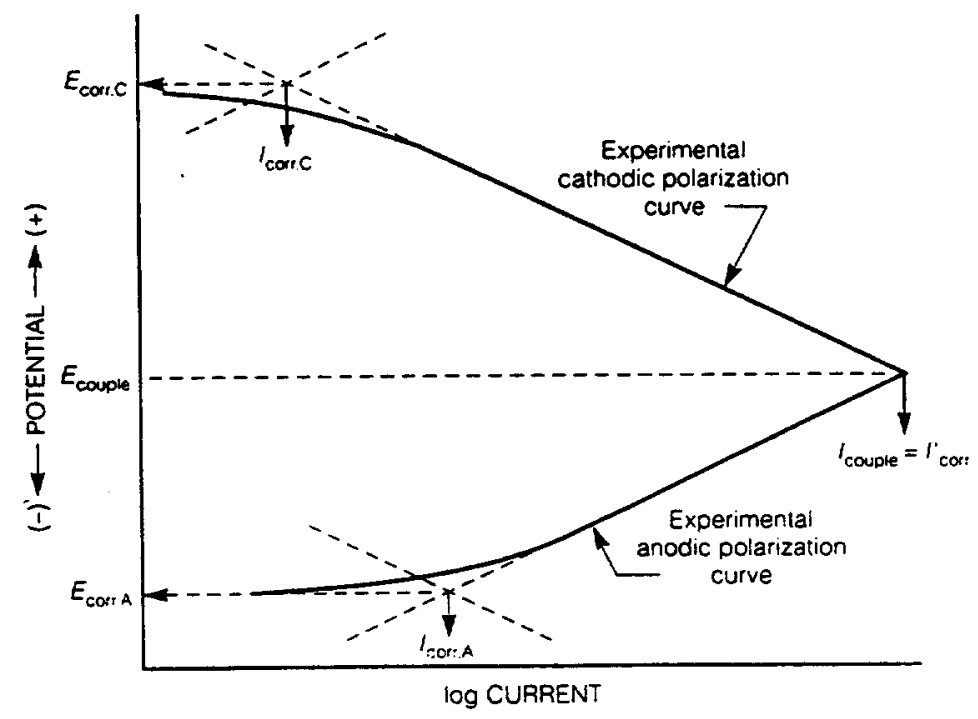

Figure 2. Schematic Experimental Polarization of Anode and Cathode in a Galvanic Couple ${ }^{()}$

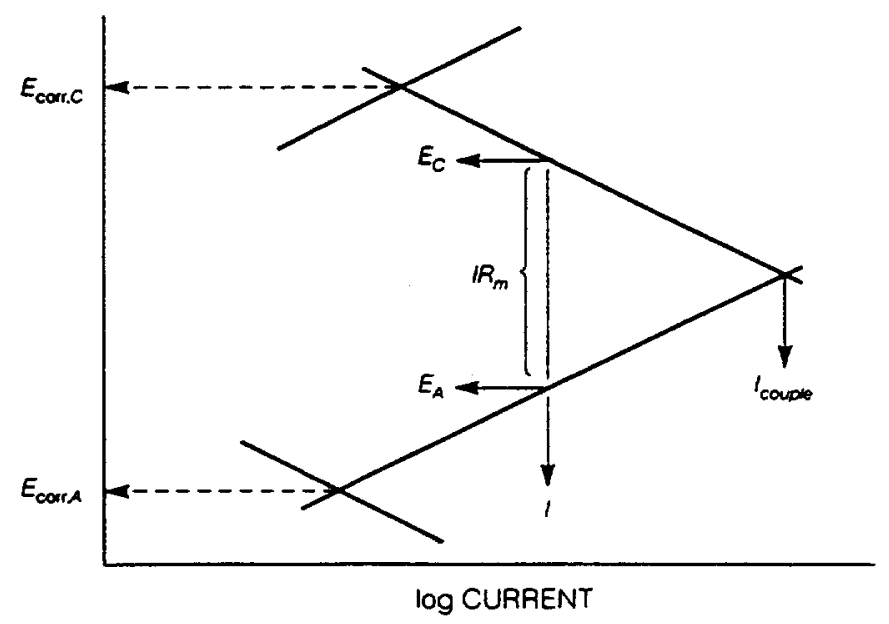

Figure 3. Reduced Galvanic Current by Insertion of an Ammeter of Resistance $R_{m}$ in a Galvanic Couple ${ }^{(\mathfrak{)})}$ 


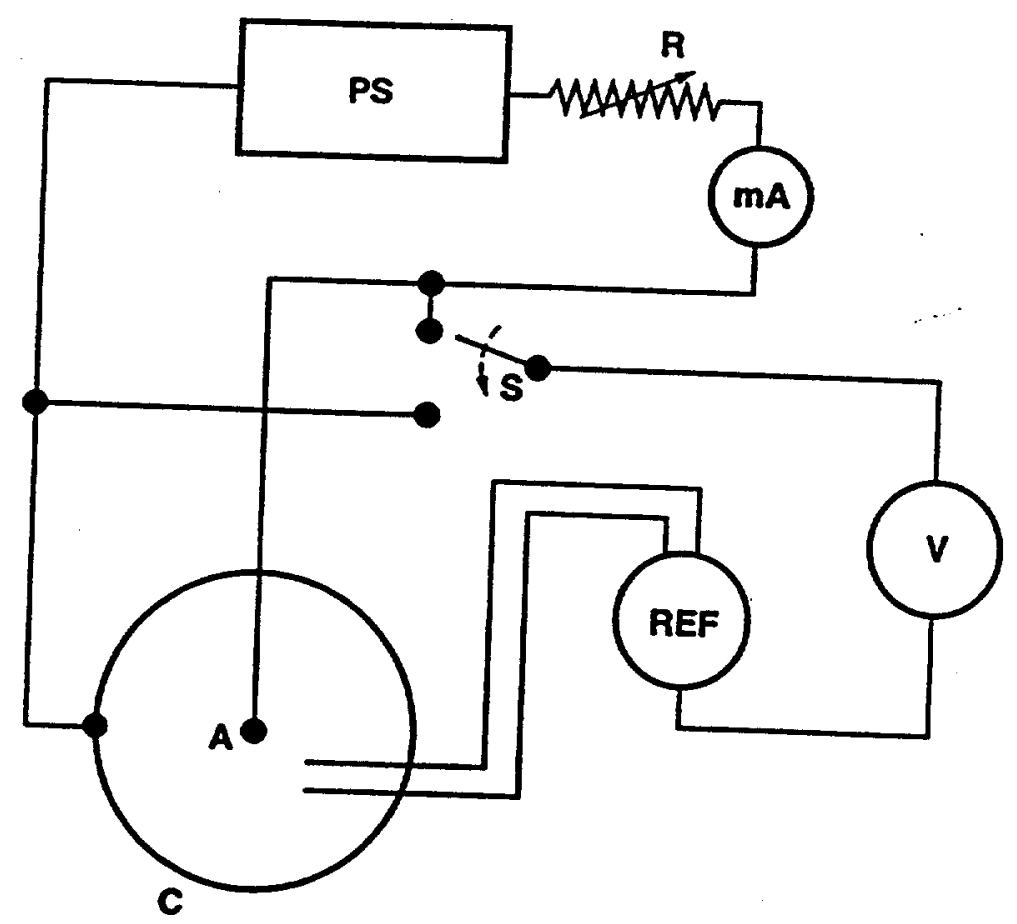

Figure 4. Zero-Resistance Ammeter (ZRA) by Controlled Current

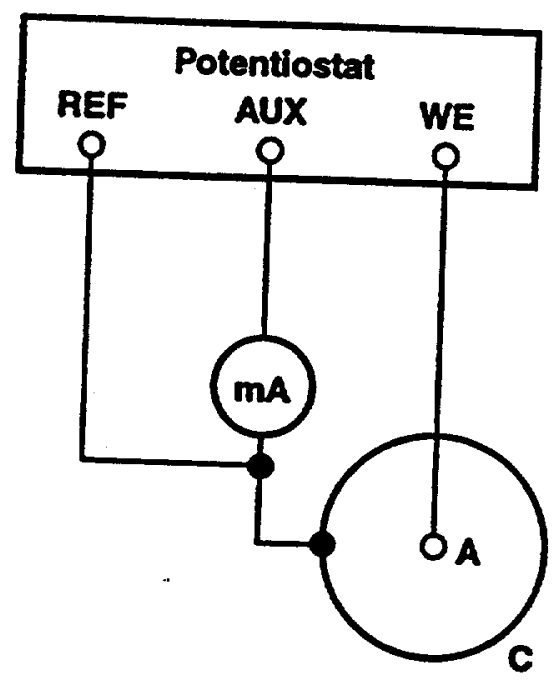

Figure 5. Zero-Resistance Ammeter (ZRA) by Controlled Pontential 


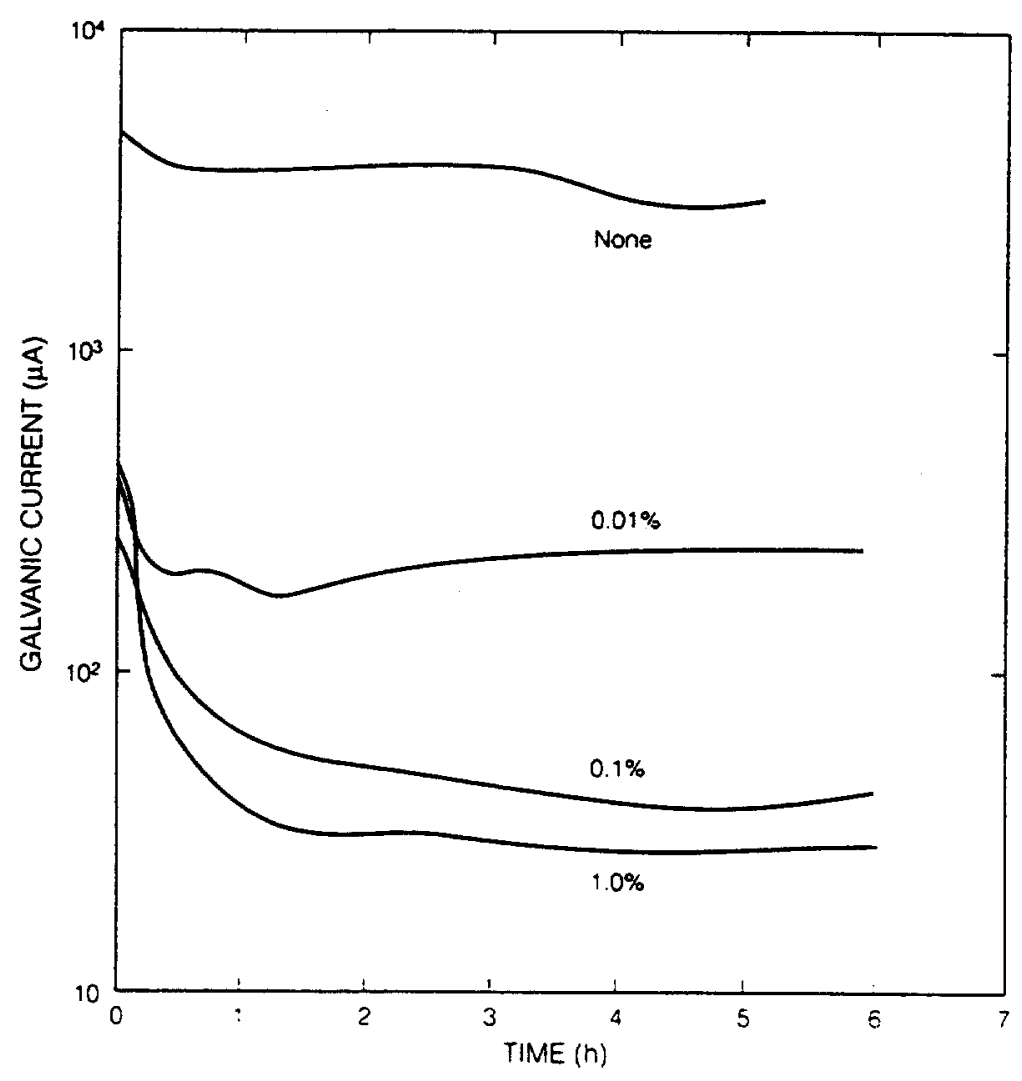

Figure 6. Continuously Recorded Galvanic Currents using the Potential-Controlled ZRA of Figure $5^{(8)}$ 


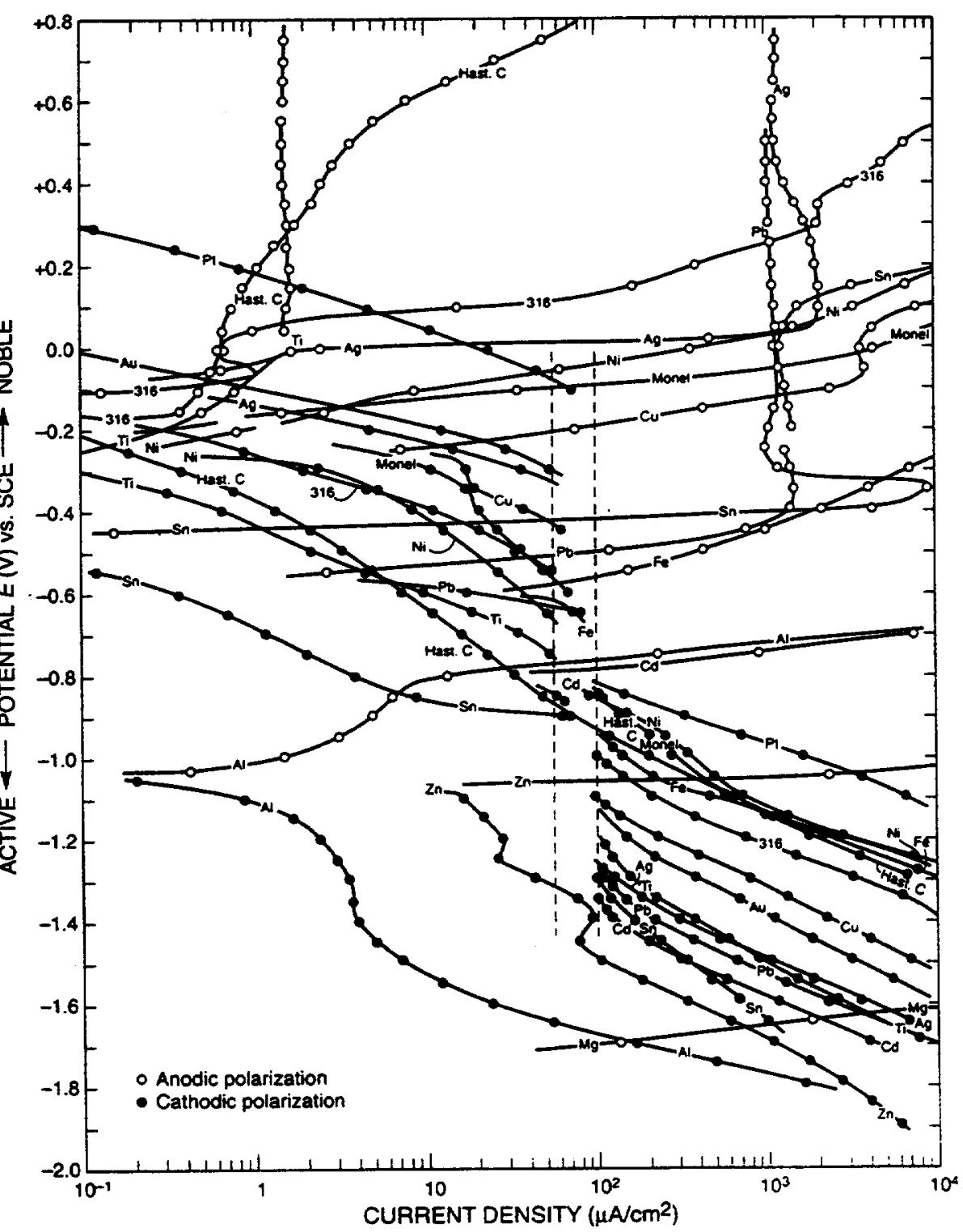

Figure 7. Potentiostatic Polarization Curves for Various Metals and Alloys for Prediction of Galvanic Corrosion in Aerated 3\% $\mathrm{NaCl}^{(9)}$ 


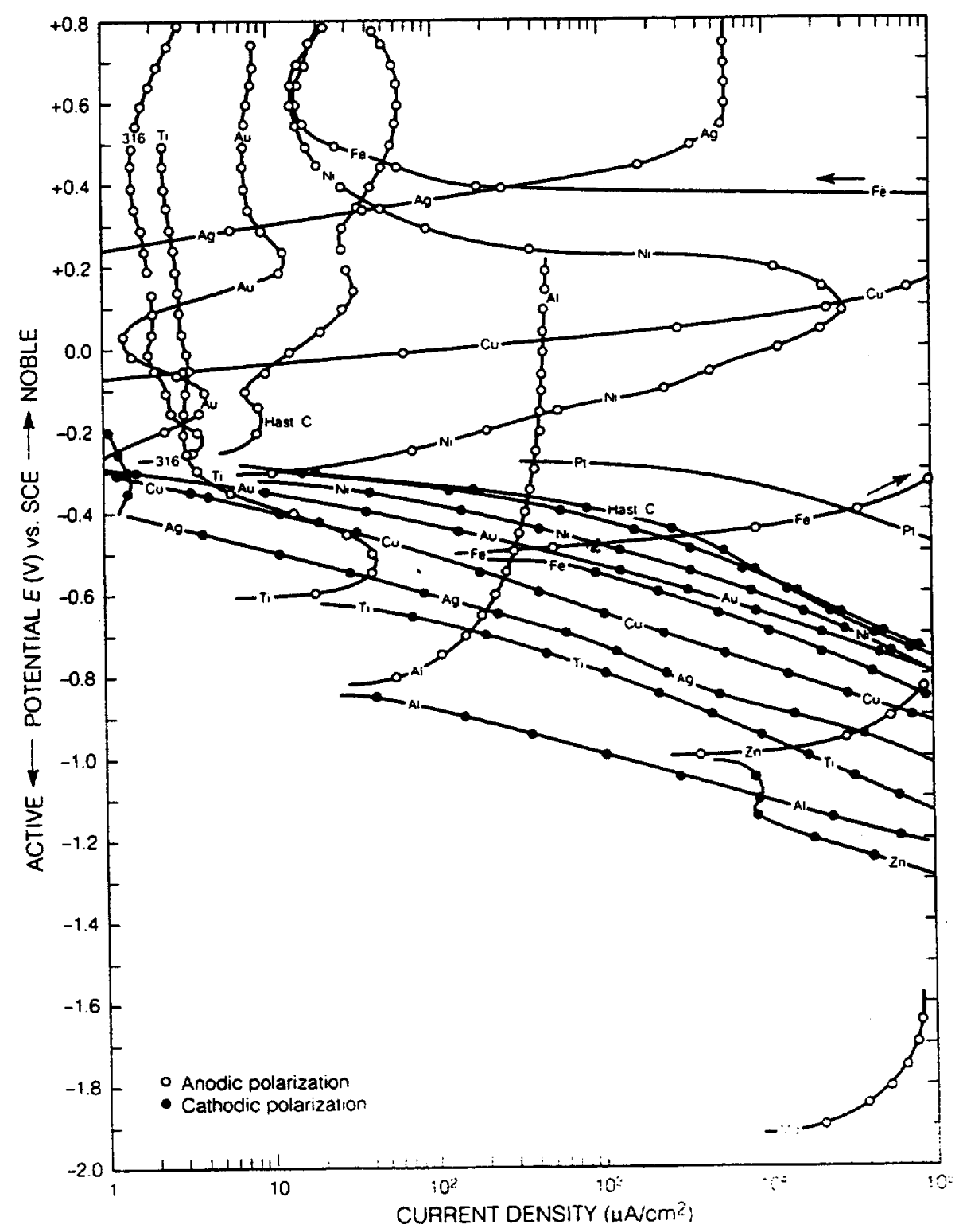

Figure 8. Potentiostatic Polarization Curves for Various Metals and Alloys for Prediction of Galvanic Corrosion in Deaerated 1- $\mathrm{N}_{2} \mathrm{SO}_{4}{ }^{(9)}$ 


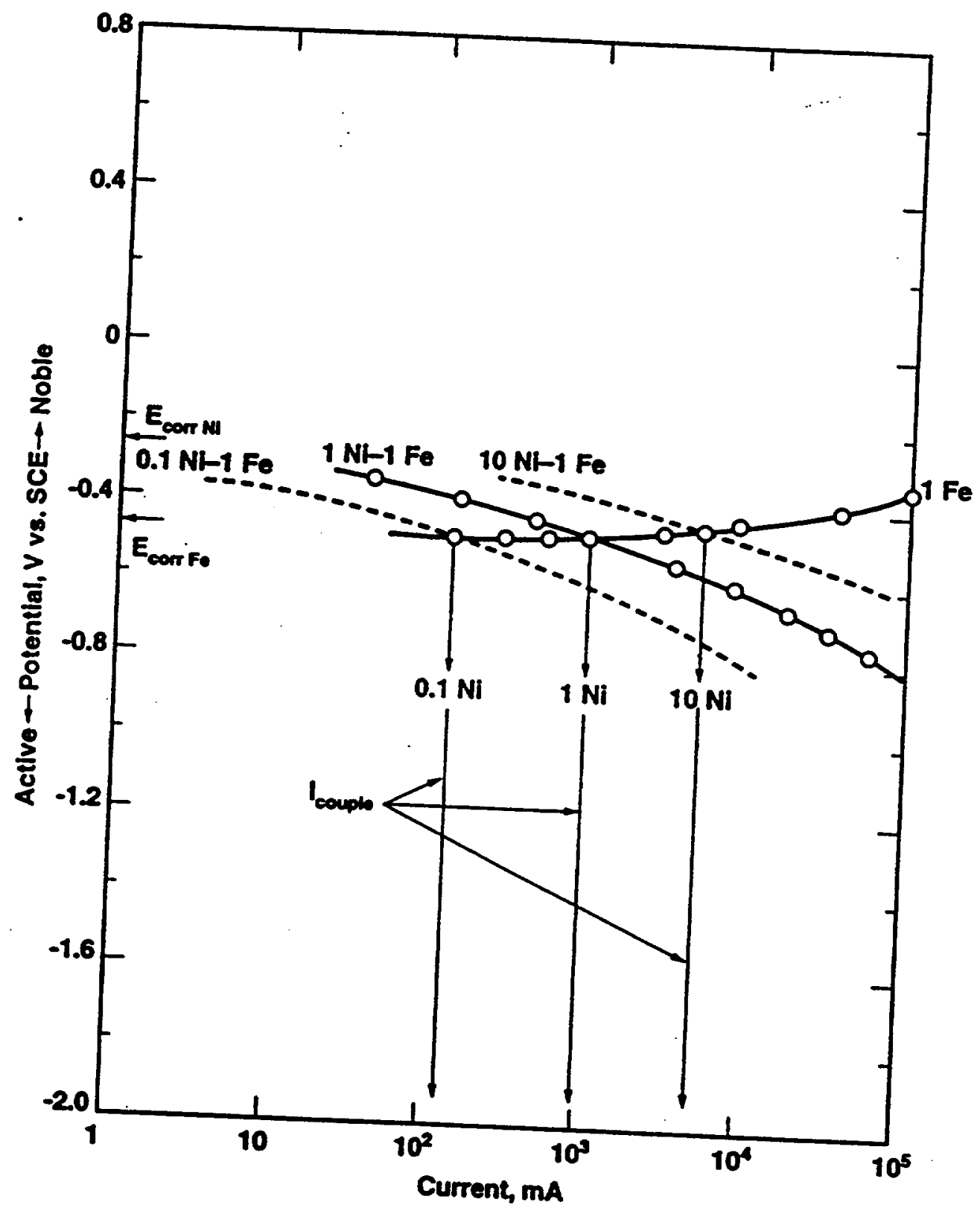

Figure 9. Galvanic Current, $I_{g}$, at the Intersection of the Cathodic Polarization Curve for $\mathrm{Ni}$ añd Anodic Polarization Curve for $\mathrm{Fe}$ in Aerated 3\% NaCl.

Curves Taken from Figure 7. 


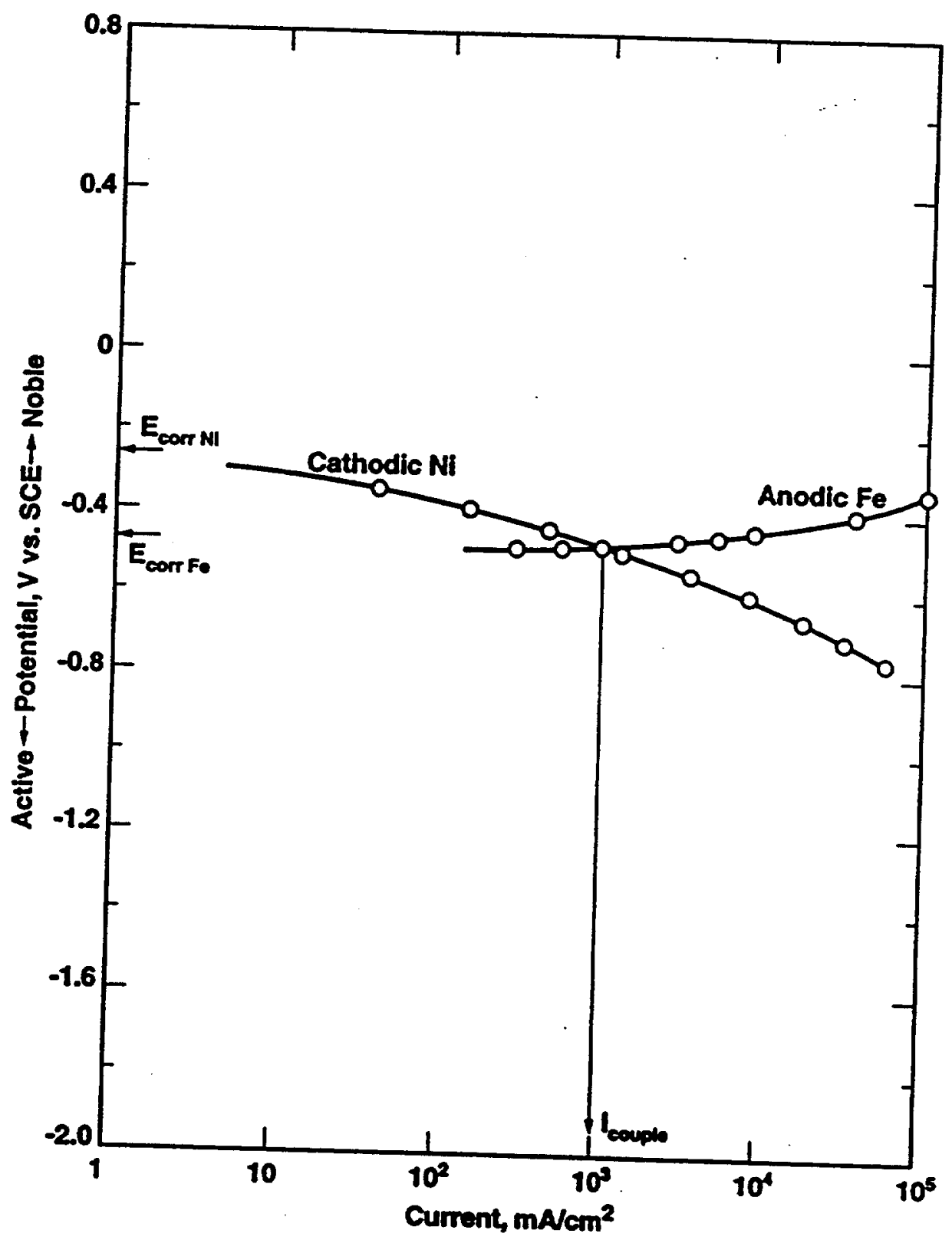

Figure 10. Galvanic Current, $\mathrm{I}_{\text {couple, }}$ at the Intersection of the Cathodic Polarization Curve for $\mathrm{Ni}$ and Anodic Polarization Curve for $\mathrm{Fe}$ in Deaerated $\mathrm{I}-\mathrm{N} \mathrm{H}_{2} \mathrm{SO}_{4}$. Curves Taken from Figure 9. 


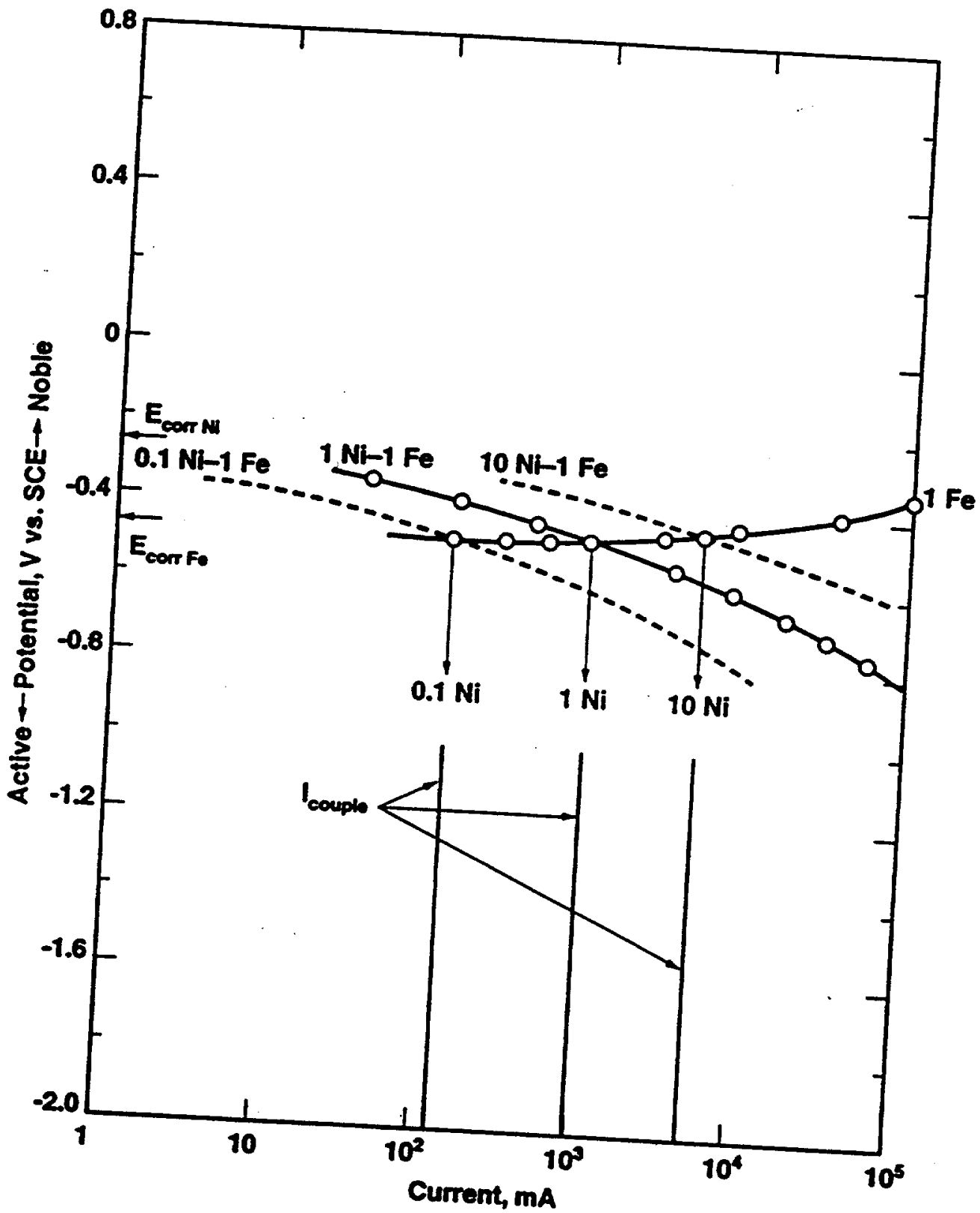

Figure 11. Effect of Increasing Area of Ni on $\mathrm{I}_{\text {couple }}$ in a Ni-Fe Galvanic Couple 

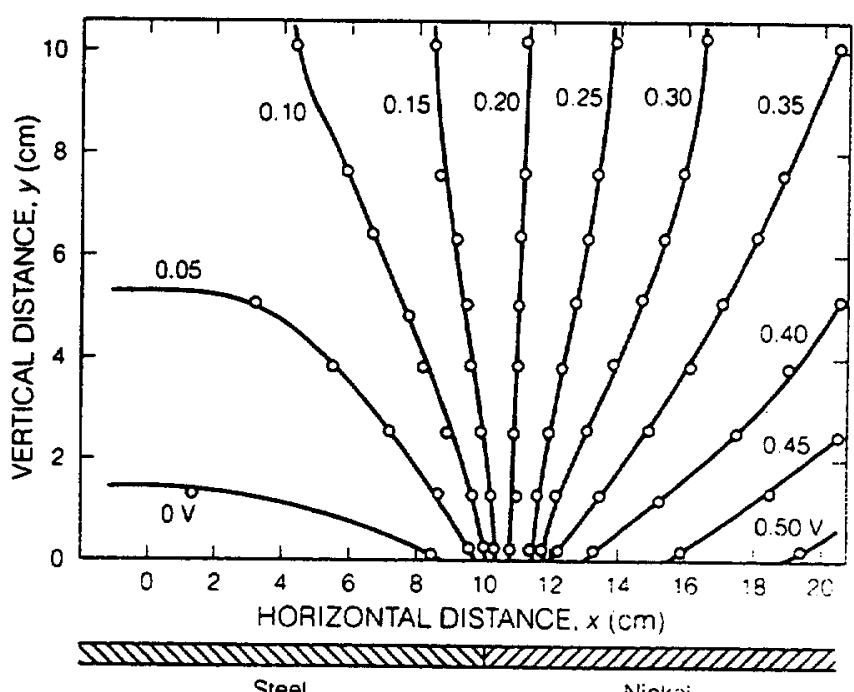

Figure 12. Potential Distribution around a Coplanar Galvanic Couple between $\mathrm{Fe}$ and $\mathrm{Ni}^{(12)}$

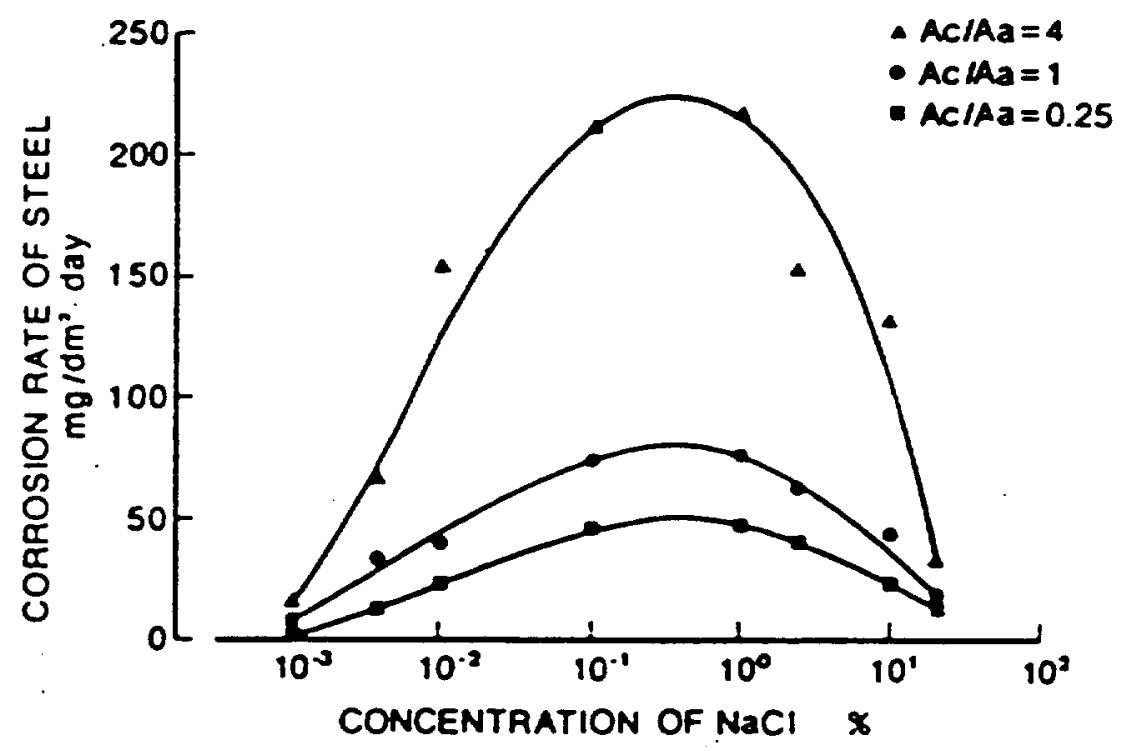

Figure 13. Corrosion Rate of Steel vs $\mathrm{NaCl}$ Concentration in Neutral Solutions at Various Cathodic to Anodic Area Ratios ${ }^{(2)}$ 


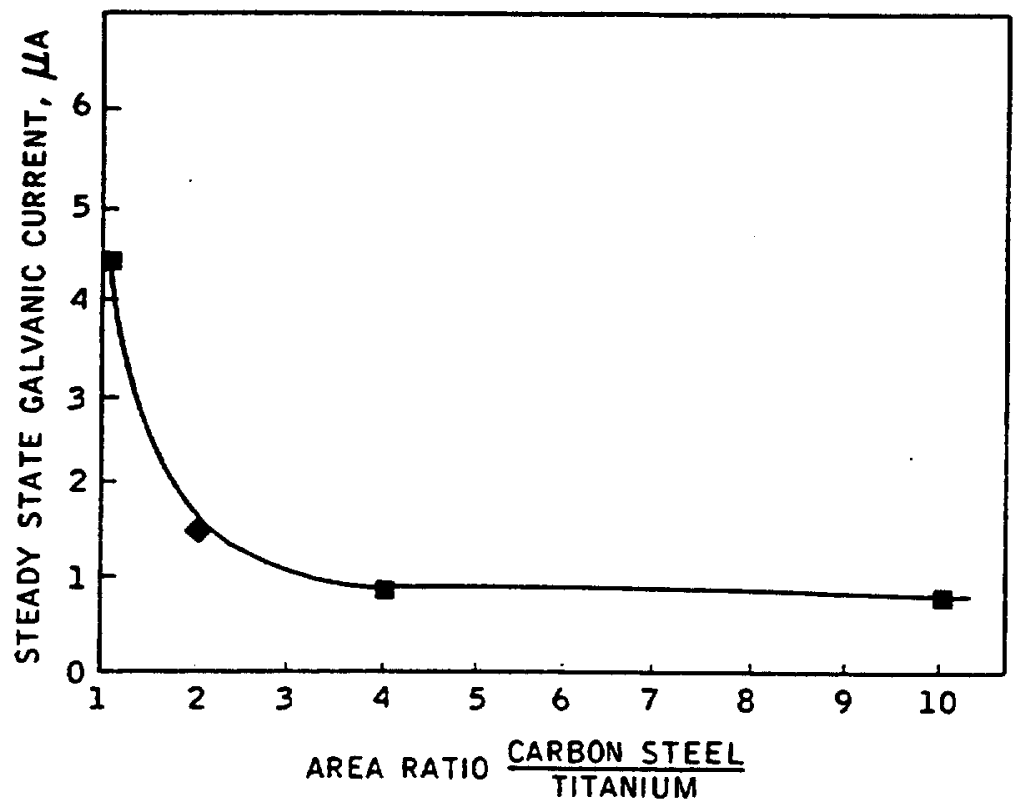

Figure 14. Variation of Galvanic Current Flowing between Ti and Carbon Steel (CS) at Different CS/Ti Area Ratios in Sulfidic Solution Containing Cyanide at $79^{\circ} \mathrm{C}^{(42)}$

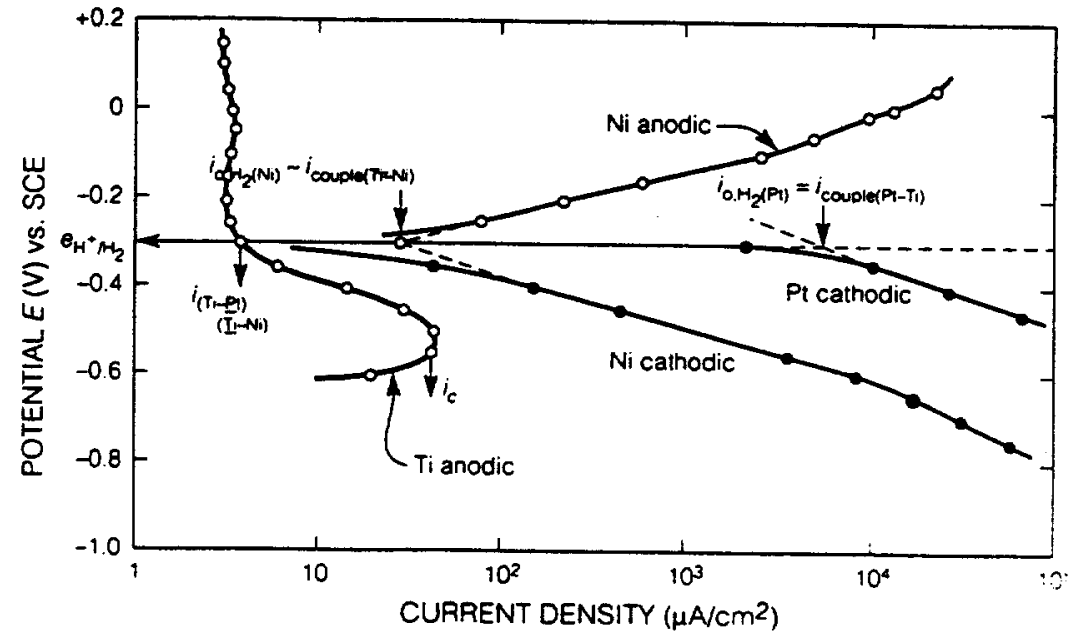

Figure 15. Galvanic Passivation of Ti when Coupled to $\mathrm{Pt}$ or $\mathrm{Ni}^{(2)}$ 


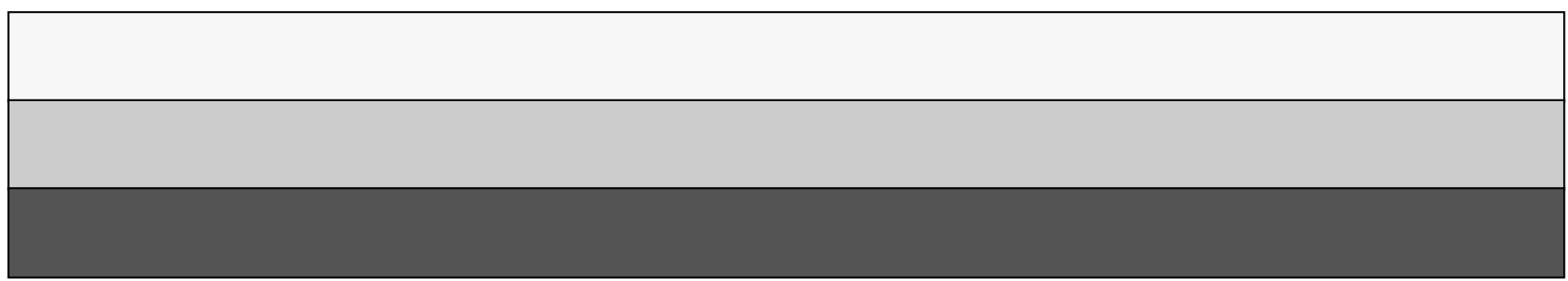

